Portland State University

PDXScholar

Spring 5-12-2015

\title{
Developing Key Sustainability Competencies through Real-World Learning Experiences: Evaluating Community Environmental Services
}

Erin Lorene Anderson

Portland State University

Follow this and additional works at: https://pdxscholar.library.pdx.edu/open_access_etds

Part of the Higher Education Commons, and the Sustainability Commons Let us know how access to this document benefits you.

\section{Recommended Citation}

Anderson, Erin Lorene, "Developing Key Sustainability Competencies through Real-World Learning Experiences: Evaluating Community Environmental Services" (2015). Dissertations and Theses. Paper 2316.

https://doi.org/10.15760/etd.2313

This Thesis is brought to you for free and open access. It has been accepted for inclusion in Dissertations and Theses by an authorized administrator of PDXScholar. Please contact us if we can make this document more accessible: pdxscholar@pdx.edu. 
Developing Key Sustainability Competencies through Real-World Learning Experiences:

Evaluating Community Environmental Services

by

Erin Lorene Anderson

A thesis submitted in partial fulfillment of the requirements for the degree of

Master of Urban Studies

Thesis Committee:

Loren Lutzenhiser, Chair

Barry Messer

Jennifer Allen

Portland State University 2015 


\begin{abstract}
This study focuses on sustainability in higher education and the competencies essential to address sustainability issues. Because sustainability issues are complex, 'wicked', and dynamic, sustainability education programs need to reflect the interdisciplinary and collaborative nature of the field. Graduates who are competent in sustainability research and problem solving will have the knowledge, skills, and attitude necessary to analyze a sustainability problem systemically and comprehensively, then will construct and implement interventions to reach optimal sustainability solutions. To prepare graduates, sustainability education programs should facilitate the development of key sustainability competencies (Wiek, Withycombe, \& Redman, 2011). Such programs provide an interdisciplinary approach that incorporates real-world sustainability issues through a combination of formal (guided by curriculum) and informal (not guided by curriculum) learning environments.

This study examines Community Environmental Services (CES), a research and service unit at Portland State University (PSU) that has been providing students informal learning opportunities connected to real-world projects. CES projects provide students opportunities to work with community partners addressing waste, recycling, and materials management issues. The intent of this research is to determine if CES provides students real-world learning opportunities not provided in traditional academic programs that facilitate the development of sustainability competencies, and positively influence students' employment opportunities post-graduation.
\end{abstract}


The findings from this research suggest that CES alumni believed they were proficient in each of the key sustainability competencies, which were developed equally through their experiences working at CES and their academic program. This study also found that CES alumni felt their experiences working at CES - including the development of professional skills and building a professional network- had more of an impact on future employment and career opportunities than their academic degree or other sources. The findings and insights from this research provide a model for sustainability education that can be replicated by other universities. A combination of formal sustainability curriculum integrated across campus, and informal real-world learning opportunities help facilitate student development of key sustainability competencies. 


\section{Table of Contents}

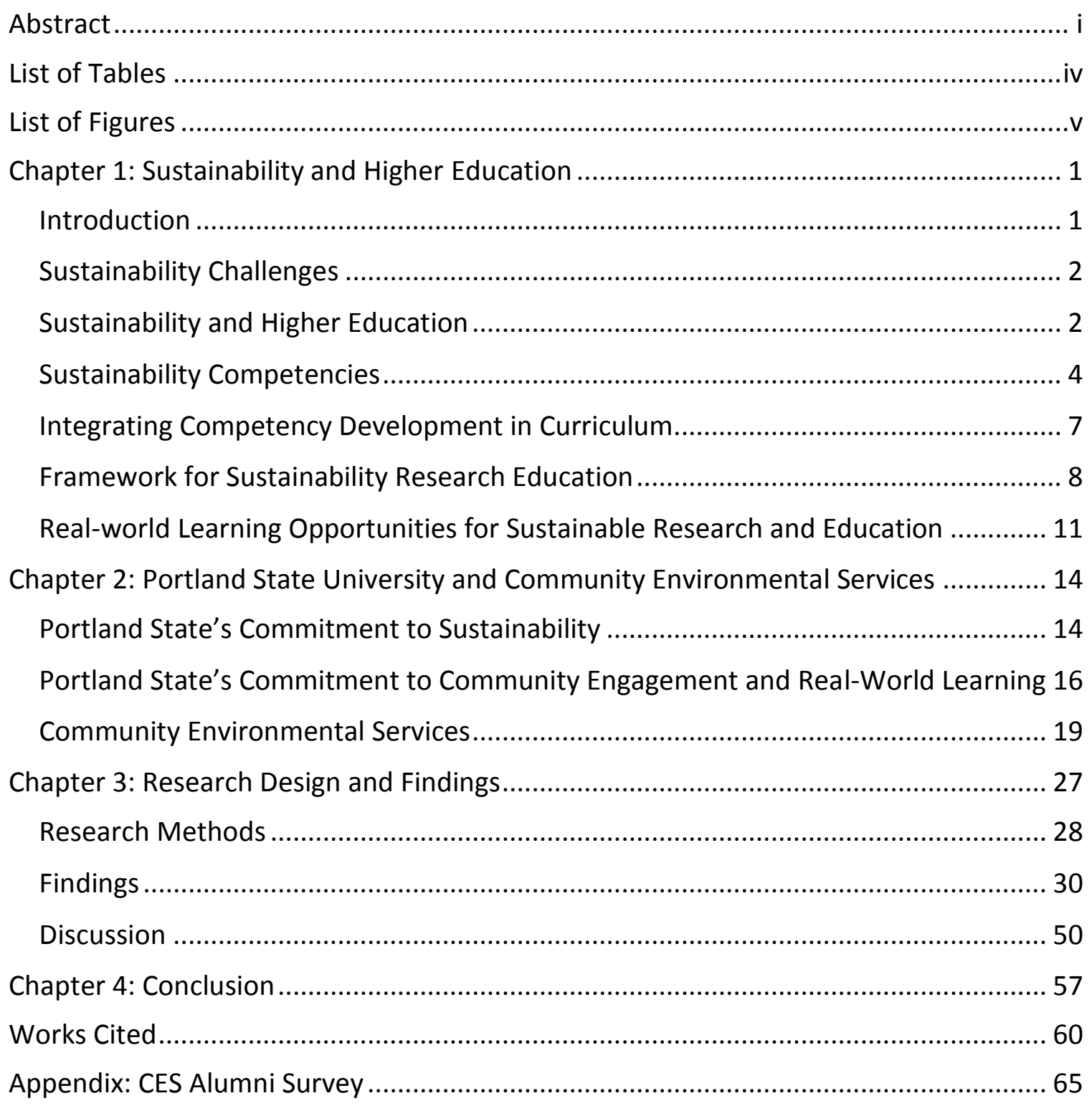




\section{List of Tables}

Table 3.1: Sustainability competency proficiency level reported by CES alumni.............. 32

Table 3.2: Attributed competency development of CES alumni. .................................. 32

Table 3.3: Survey responses by college, academic degree, and level. ............................ 34

Table 3.4: Sustainability competency proficiency level reported by CES alumni, sorted by

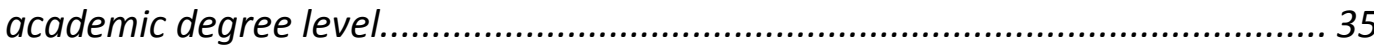

Table 3.5: Attributed competency development of CES alumni by level of academic program.

Table 3.6: Sustainability competency proficiency level reported by CES alumni, sorted by college and school. 38

Table 3.7: Attributed competency development of CES alumni by college and school. ... 40

Table 3.8: Sustainability competency proficiency level reported by CES alumni, sorted by academic program in the College of Public and Urban Affairs.

Table 3.9: Attributed competency development by program in the College of Urban and

Public Affairs. 44

Table 3.10: Additional skills and knowledge. 46

Table 3.11: Reported impact on career opportunities by level of academic degree. ...... 47

Table 3.12: Reported impact on career opportunities by academic college or school..... 47

Table 3.13: Reported impact on career opportunities by academic degree in the College of Urban and Public Affairs. 47

Table 3.14: Explanation of impact on career opportunities. 49 


\section{List of Figures}

Figure 1.1: Sustainability research and problem-solving framework with key sustainability competencies (Wiek, Withycombe, \& Redman, 2011).....

Figure 1.2: Framework of requirements for sustainability research education (Brundiers

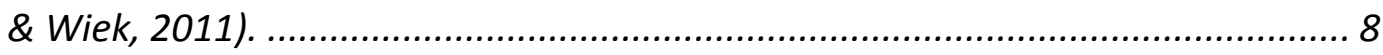




\section{Chapter 1: Sustainability and Higher Education}

The following study is organized into four (4) chapters, followed by an appendix with supplemental documents. This first chapter provides the theoretical framework surrounding sustainability in higher education and key sustainability competencies. Building on the theoretical framework, Chapter 2 utilizes Portland State University (PSU) to explore how sustainability can be integrated across campus reinforcing PSU's identity as an engaged university. The last section of that chapter focuses on the operational structure of Community Environmental Services (CES), a research and service unit at PSU. Chapter 3 introduces the research specific to this study that focuses on the development of key sustainability competencies by CES alumni, and impacts on their employment opportunities post-graduation. The final chapter looks at what additional research could supplement this study and the current body of literature.

\section{Introduction}

This study is on sustainability in higher education and the competencies essential to address sustainability issues. Because sustainability issues are complex, 'wicked' and dynamic, sustainability education programs need to reflect the interdisciplinary, cocurricular, and collaborative nature of the field (Batie, 2008; Rittel \& Webber, 1973). This research focuses on Community Environmental Services (CES), a research and service unit employing students at Portland State University (PSU) specializing in waste, recycling, and materials management. Student employees provide high-quality research, technical assistance, data collection, and educational outreach services to local partners. 
The intent of this research is to determine if CES provides students real-world learning opportunities not provided in traditional academic programs that facilitate the development of sustainability competencies, and positively influence students' employment opportunities post-graduation.

\section{Sustainability Challenges}

The emerging sustainability field has been focused on addressing the complex challenges facing society today-including climate change, resource depletion, poverty, public health, and other social inequities - and has led to an awareness that "society is unprepared to fully understand, let alone cope with, these challenges" (Wiek, Withycombe, Redman, \& Mills, 2011, p. 2). This awareness has resulted in an emerging academic field focused on providing collaborative community-based research, and preparing graduates to be change-agents and systemic-problem solvers to address and solve these complex sustainability issues (Wiek, Withycombe, \& Redman, 2011; Wiek, Withycombe, Redman, \& Mills, 2011).

\section{Sustainability and Higher Education}

In 2002 the United Nations declared a Decade of Education for Sustainable Development (2005-2014) "emphasizing that education is an indispensable element for achieving sustainable development" and encouraging integration of sustainable education at all levels and in all learning contexts (United Nations, 2008). Following the UN declaration, the National Council for Science and the Environment hosted a conference on Education for a Sustainable and Secure Future where the U.S. Partnership 
for Education for Sustainable Development was established (Rowe, 2007). The U.S. Partnership consists of a network of individuals, organizations, and institutions working across all sectors to educate for a sustainable future. Three major efforts surfaced within the higher education sector, the Higher Education Associations Sustainability Consortium (HEASC), the Disciplinary Associations Network for Sustainability (DANS), and the Association for the Advancement of Sustainability in Higher Education (AASHE). Each has a different focus aimed at integrating sustainable education into all aspects of higher education including curricula, professional development, facilities and operations, student affairs, and campus activities (Rowe, 2007).

As sustainability becomes integrated into higher education, sustainability education programs should be focused on building student capacity to fully understand and manage sustainability challenges, and preparing them to be "systemic-problem solvers, change agents, and transition managers" (Wiek, Withycombe, \& Redman, 2011, p. 204). Two theories of pedagogy are thought to have shaped higher education in the United States according to Louis Menand. The first considers college a four-year intelligence test that prepares students to continually demonstrate the knowledge they have gained. The second, a democratic pedagogy, assumes the purpose of college is to expose students to academic experiences that will empower them as future citizens, regardless of their post-graduation career path (Park, 2014). In order to fully prepare students to address today's sustainability challenges, higher education needs to find innovative ways to provide students with learning opportunities focused on challenges 
and solutions while providing the framework of systems thinking, interpersonal, and change agent skills (Rowe, 2007).

\section{Sustainability Competencies}

Critical to development of sustainability programs are a set of commonly shared learning outcomes and key competencies to provide a framework for the academic field in which to evaluate student learning and teaching effectiveness. Competencies also provide a profile of recognizable qualifications in the field for sustainability research, teaching, and professional work (Wiek, Withycombe, Redman, \& Mills, 2011). Key sustainability competencies differ from traditional competencies, such as critical thinking and communication, because they are considered essential for addressing sustainability issues and often are not the focus of higher education programs (Wiek, Withycombe, \& Redman, 2011). To prepare students, traditional competencies should be the foundation upon which sustainability competencies are developed. Wiek, Withycombe, and Redman (2011) present five key sustainability competencies that prepare graduates to analyze a sustainability problem and construct interventions to reach sustainable solutions.

Systems-thinking competence is the ability to analyze complex systems across different fields (environment, society, economy, etc.) and scales (local to global) while considering systemic features and problem-solving frameworks. Systems-thinking competence ensures the capacity to understand the present status and underlying 
causes of complex sustainability problems, while considering the direct and indirect effects of various inputs or interventions on the system.

Anticipatory competence is the ability to analyze, evaluate, and articulate the long-term future of various sustainability issues, including unintended consequences and inter-generational equity. Anticipatory competence enables forecasting and sustainability visioning that anticipates and prevents harmful unintended consequences.

Normative competence is the ability to convey, apply, and negotiate sustainability values, goals, and targets. This includes the ability to first assess the current issue and the ability to create a more sustainable vision for that issue. Normative competence evaluates sustainability issues while considering the justice, equity, social-ecological integrity, and ethics of sustainable development.

Strategic competence is the ability to "get things done" by designing and implementing interventions and transformative strategies toward improved sustainability. This requires familiarity with real-world situations, political understanding of power structures and relationships, the ability to convey technical issues in layman's terms, and to complete tasks within deadlines. Strategic competence links knowledge to action to enable transitions toward a sustainable future.

Interpersonal competence is the ability to motivate, enable, and facilitate collaborative and participatory sustainability research and problem solving. This includes the ability to understand, compare, and critically evaluate different positions, perspectives, and preferences across cultures, social groups, communities, and 
individuals. Interpersonal competence is an important component of the other competencies, which all rely on collaborative and inclusive approaches to solutions.

Figure 1.1 below provides an integrated sustainability research and problemsolving framework and the intersection of the five key competencies (shaded in grey and connected to each module of the framework by dotted lines and arrows).

Sustainability problems are first analyzed in their current state utilizing systems-thinking and normative competencies, then anticipatory and normative competencies facilitate the consideration of non-intervention scenarios and the creation of various sustainability visions. Strategic competence is essential to implement and test strategies that transform from the current state to a sustainable state while interpersonal competence is essential for all components of the research and problem-solving framework (Wiek, Withycombe, \& Redman, 2011).

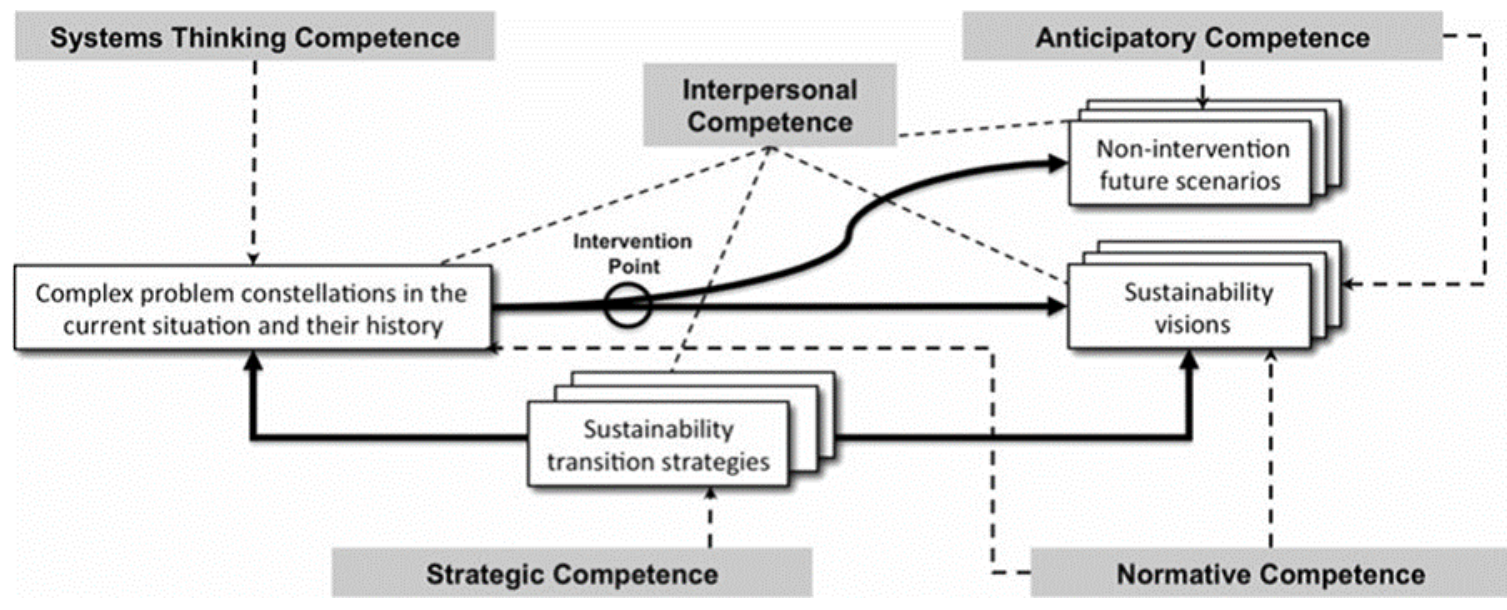

Figure 1.1: Sustainability research and problem-solving framework with key sustainability competencies (Wiek, Withycombe, \& Redman, 2011). 
Overall competence in sustainability research and problem-solving requires the development of each individual key competency as well as the ability to effectively combine competencies to "enact changes in economic, ecological and social behavior without such changes always being merely a reaction to pre-existing problems" (de Haan, 2006, p. 22).

\section{Integrating Competency Development in Curriculum}

"Competencies are described as learnable but not teachable" (Barth, Godmann, Rieckmann, \& Stolenberg, 2007, p. 418) and it has been argued that traditional academic programs do not provide opportunities for students to develop key sustainability competencies (Calder \& Clugston, 2007; Rowe, 2007; Brundiers \& Wiek, 2011; Park, 2014). Before competencies can be developed, sustainability education and problem solving must be integrated into academia and curriculum development in a manner that encourages, rather than hinders competency development. Sustainability education is a field that should not be defined by traditional disciplines but should incorporate the methods, theories, and knowledge from a variety of disciplines (Wiek, Withycombe, Redman, \& Mills, 2011). Sustainability education requires what has been termed "epistemological pluralism" to "enhance the capacity for more fully integrative research and education" (Miller, Baird, Littlefield, Kofinas, \& F. Stuart Chapin, 2008, p. 46) valuing diverse perspectives on knowledge and problem solving (Wiek, Withycombe, Redman, \& Mills, 2011). In order for sustainability competencies to be valued outside of academia, an evaluation method must be developed and conveyed to professionals 
identifying the skills graduates possess, and how they can be applied to real-world sustainability issues. This will require more collaboration between academia, business, and government to make "sustainability education more practical and sustainability practice more effective" (Wiek, Withycombe, Redman, \& Mills, 2011, p. 11).

\section{Framework for Sustainability Research Education}

Responding to the call for developing sustainability curriculum that connects students' education with actual sustainability problems and engaged stakeholders (Rowe, 2007), Katja Brundiers and Arnim Wiek developed a framework for sustainability research education (2011). The framework consists of seven components that bridge stakeholders and academia, including professors and students. Figure 1.2 below illustrates Brundiers and Wiek's framework.

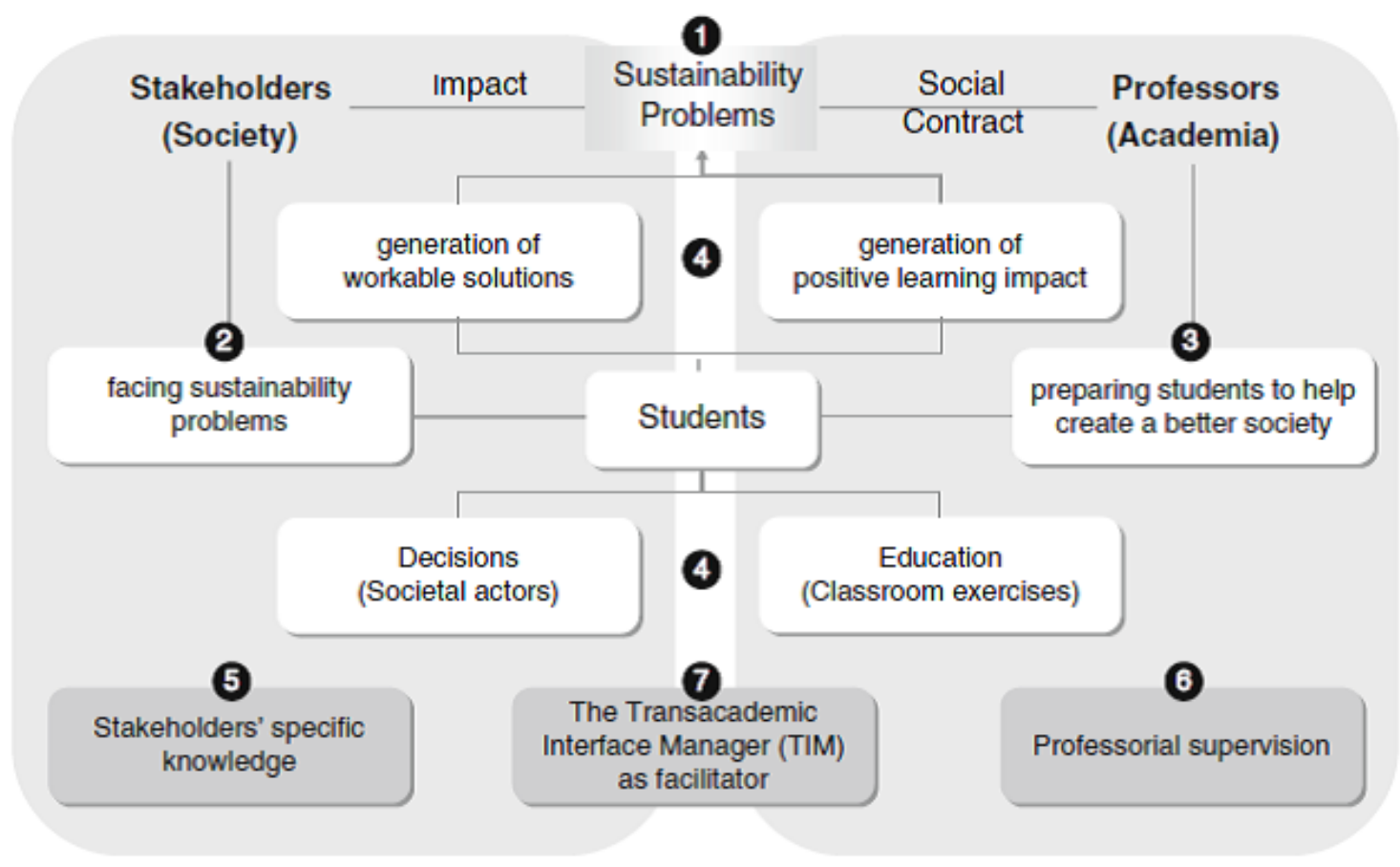

Figure 1.2: Framework of requirements for sustainability research education (Brundiers \& Wiek, 2011). 
Brundiers and Wiek identify the seven framework components as:

\section{Actual Sustainability Problems}

Sustainability issues are often wicked problems that are complex, long term, require urgent attention and cannot be fixed simply with technical solutions (Liu et al., 2007). Utilizing actual sustainability problems in educational programs allows students to move beyond the theoretical and "develop practical competence, commitment, and the skills needed to disseminate their research" (Brundiers \& Wiek, 2011, p. 110).

\section{Stakeholders Facing the Sustainability Problems}

Sustainability problems need to be solved by stakeholders and decision-makers who may often be more willing to implement solutions when they have initiated the problem-solving process in collaboration with academics.

\section{Preparing Students to Help Create a Better Society}

As universities aim to prepare students who are capable of helping to create a better society or who are change agents for sustainability, sustainability research education must connect the technical or scientific expertise with competencies that promote stewardship.

\section{Generation of Workable Solutions and Positive Learning Impact}

"Sustainability research education should enable students to analyze a sustainability problem and to develop the response and mitigation strategies collaboratively with stakeholders" (Brundiers \& Wiek, 2011, p. 111). This will increase the likelihood that solutions will be implemented and lead to real-world changes. Transacademic research, 
where scholars and stakeholders collaboratively conduct research, allow students opportunities to contribute to a collective problem-solving process.

\section{Stakeholders' Specific Knowledge}

Stakeholder collaboration in research provide students exposure to industry knowledge, preferences, and practical experiences that will help to develop a feasible solution. Students are provided settings where they can learn to build partnerships and trust by integrating different types of information, knowledge, values, and perceptions.

\section{Professorial Supervision}

Sustainability research builds on traditional academic skills such as critical thinking, effective writing, and presenting research findings. Professors should enhance these skills while facilitating development of skills through sustainability research. This will require professors to be "flexible and adaptive and willing to go beyond disciplinary boundaries" (Brundiers \& Wiek, 2011, p. 111).

\section{The Transacademic Interface Manager as Facilitator}

Transacademic research (research that spans beyond the university) inherently requires additional support to address unique institutional and organizational challenges that arise between participants (stakeholders, professors, and students). The Transacademic Interface Manager (TIM) facilitates successful collaboration between academics and practitioners and provides project management oversight to ensure the alignment of sustainability research and real-world knowledge and practice. In addition to professorial supervision, students benefit from project management and professional 
skill development guided by the TIM. The additional support from the TIM allows participants to focus on their role in the sustainability research and problem-solving process.

The above framework can be used to evaluate existing sustainability programs as well as guide the development of new programs focused on real sustainability issues and solutions.

\section{Real-world Learning Opportunities for Sustainable Research and Education}

Throughout the sustainability competency literature, real-world learning opportunities are cited as essential components of sustainability programs. A transdisciplinary approach - where academics collaborate with stakeholders throughout the entire process to identify the problem and develop solutions - is a valuable method for aligning student competency development and the creation of innovative solutions (Brundiers, Wiek, \& Redman, 2010; Wiewel, Kecskes, \& Martin, 2011; Robinson, 2008). Transdisciplinary approaches can transition sustainable solutions from the "order, deliver, and pick up" model where stakeholders "pick up" a solution from academics, to a model where stakeholders are developing innovative solutions with academics while facilitating student transitions from the classroom to a career in sustainability (Brundiers \& Wiek, 2011; Bailey \& Keen, 2014).

Collaborating with non-academic stakeholders exposes students to challenges, communication styles, deadlines, politics, and limitations that cannot be experienced in a classroom that help to develop sustainability competencies and accountability (Wiek, 
Withycombe, Redman, \& Mills, 2011; Brundiers, Wiek, \& Redman, 2010). Collaborating with professionals and working on real-world sustainability issues provide skills, experiences, and networking opportunities that better prepare students for a career post-graduation (Brian \& Thomas, 2013). While real-world learning provides students opportunities that cannot be translated to traditional classroom curriculum it does not guarantee that students develop all sustainability competencies (Brundiers, Wiek, \& Redman, 2010). Informal real-world learning opportunities can facilitate student development of sustainability competencies. Informal learning opportunities occur outside of the formal educational sphere and are not guided by an organized academic curriculum. Schugurensky (2000) classified informal learning into the following three forms with varying levels of intention and consciousness (or awareness) at the time of the learning experience:

- Self-directed learning refers to specific projects undertaken by individuals or groups without the guidance of an educator. This type of informal learning is intentional because individuals are seeking out the project and is conscious because they are aware they are learning through the process.

- Incidental learning occurs without previous intention of learning from an experience, but after individuals become aware that some learning occurred. This form of learning is unintentional but conscious. 
- Socialization (also known as tacit learning) refers to the internalization of values, behaviors, and skills that occur during every day experiences. This learning is unintentional and individuals are not aware they learned something during the experience.

A combination of both formal and informal learning should be included in sustainability education programs to facilitate student development of sustainable competencies (Barth, Godmann, Rieckmann, \& Stolenberg, 2007). Formal learning experiences provide guidance and a framework for developing sustainability competencies while informal learning opportunities allow students to use that framework, complementing what they have learned. This allows for additive learning where students are strengthening the knowledge and skills they develop. Formal and informal learning experiences can also provide students opportunities to challenge and contradict the current paradigm creating a transformative learning experience that challenges their values, knowledge, and skills (Schugurensky, 2000).

The next chapter utilizes the theoretical foundation discussed above and evaluates Portland State University's efforts to integrate sustainability education and real-world learning opportunities across campus. Community Environmental Services (CES), a research and service unit at PSU, is assessed as an organization providing students with informal learning opportunities. 


\section{Chapter 2: Portland State University and Community Environmental Services}

The following chapter moves from theory to practice by examining the integration of sustainability education and real-world learning opportunities at Portland State University (PSU). PSU is an urban research university located in downtown Portland with more than 28,000 students, 8 schools, and 226 degree programs (Portland State University, 2015d).

\section{Portland State's Commitment to Sustainability}

In 2005, PSU formally adopted a Declaration of Support for Sustainability that recognized the university's responsibility and role in developing sustainable solutions to improve the quality of life for current and future generations (Portland State University, 2013a). This declaration identifies the following four actions that will establish a vision of sustainability in both academics and operations (Portland State University, 2013a).

Action 1) Infuse sustainability into all colleges, schools and programs.

Action 2) Develop a sustainable physical campus that is an example to other institutions.

Action 3) Make Portland State University a demonstration model of sustainable processes and practices.

Action 4) Develop core multidisciplinary research competencies in key sustainability areas related to pressing real world problems.

Throughout each action, collaboration with businesses, governments, and local communities is prioritized to develop and implement sustainable solutions. Additionally, 
the university's vision is to be recognized for contributing to the "economic vitality, environmental sustainability, and quality of life in the Portland region and beyond" through student learning, innovative research, and community engagement (Portland State University, 2015c). Sustainability is one of eight learning outcomes to be incorporated campus-wide, at both the course and program development levels. Within PSU's Strategic Plan (2011-2014), "achieving global excellence" is identified as a priority that includes a goal to "establish PSU as a recognized regional resource for globally relevant research, practice, and education in sustainability" (Portland State University, 2014, p. 15). To accomplish this PSU will focus on the following:

- Enhancing its current reputation as a leader in sustainability.

- Cultivate relationships among departments at PSU to encourage sustainable practices across campus.

- Support the development and integration of sustainability across curriculum.

- Increase the regional and national visibility of PSU's role in sustainability research.

In 2008, PSU was awarded a 10-year, \$25 million challenge grant to advance the university as a leader in sustainability research, education, and outreach. The Institute for Sustainable Solutions (ISS) administers the grant, and is focused on supporting interdisciplinary research, curriculum development, student leadership, and community partnerships at the university (Portland State University, 2015b). ISS serves as the hub of 
sustainability at PSU by creating campus cohesion around sustainability and facilitates connections with community partners focusing on innovative solutions. In December 2013, ISS and other campus partners developed the Sustainability at Portland State University Playbook 2013-2018 that guides future work toward effective assessment and institutionalization of sustainability. Six focus areas, with accompanying goals and initiatives, were developed to guide sustainability research and education at PSU during the five-year period. The six focus areas are education and curriculum, student experience and engagement, research, community engagement, campus operations, and institutional policies and administration (Portland State University, 2013b). Community engagement is one focus area where PSU has a rich history to help achieve these sustainability goals.

\section{Portland State's Commitment to Community Engagement and Real-World Learning}

Community engagement and a relationship where "knowledge serves the city and the city contributes to the knowledge of the University" is embedded in PSU's mission and values (Portland State University, 2015c). This includes creating opportunities for students to apply their knowledge to real-world problems and creating relationships with partners that are valued and reciprocal.

In the early 1990s, PSU was in the midst of establishing its identity as an urban university and began evaluating student learning outcomes within that context (Kecskes, Kerrigan, \& Patton, 2006; Wiewel, Kecskes, \& Martin, 2011). To attract and retain students during an economic struggle, PSU focused on becoming a student- 
centered institution utilizing applied learning pedagogies (Kecskes, Kerrigan, \& Patton, 2006). This led to the creation of the interdisciplinary University Studies program for undergraduate students. The primary goals of the program included; 1 ) inquiry and critical thinking, 2) communication (written, oral, visual, quantitative, group, technological), 3) diversity of human experience, and 4) social responsibility and ethical issues (Kecskes, Kerrigan, \& Patton, 2006). Faculty were challenged to use applied and experiential learning strategies and consider different methods for learning and research. This complemented the interdisciplinary knowledge base of participating students and community partners. Because the University Studies program and community-based learning was new to many faculty, PSU established a development center that provided support for faculty to integrate community-based learning into their courses (Kecskes, Kerrigan, \& Patton, 2006). In addition to supporting faculty to integrate community-based learning into their curriculum, PSU provided support to develop and cultivate relationships with partners. It quickly became evident that longterm partnerships were needed to provide stability to the program and continued value to the partners. Since the inception of the University Studies program, all departments across campus have integrated community-based learning strategies and offer classes that connect students with community partners (Kecskes, Kerrigan, \& Patton, 2006).

Nearly two decades after PSU first emerged as an engaged university, PSU has become a national leader in community-based learning and research strategies. Once again facing an economic struggle and institutional challenges, a "second ( $r$ )evolution" 
emerged to expand community-based and engaged research strategies and to continue transforming the university and community (Wiewel, Kecskes, \& Martin, 2011). As discussed by Wiewel, Kecskes, and Martin (2011), the following five areas have been identified as critical for the university's expanding partnership efforts.

\section{Community-based learning.}

It is critical to expose students to community organizations and institutions through community-based learning, to develop scholars and engaged citizens who are connected and have a sense of ownership of local challenges and opportunities. This not only provides students with real-world experiences creating a foundation to continue contributing to the community, but also establishes connections with potential employers and increases the value of a PSU degree to potential employers.

\section{Expanding research partnerships in key areas.}

As PSU expands its research to address the problems and opportunities relevant to the regional community, a transdisciplinary research approach will ensure research that is focused on the issues community partners want solved. Researchers will be encouraged to collaborate with other institutions and a variety of community partners to inspire innovative solutions to complex issues.

\section{Taking problem sets from the community.}

PSU's dedication to community-based learning goes beyond connecting students to the community and includes integrating issues that directly challenge the local community into all aspects of curriculum. 
Expanding PSU's international partnership initiatives.

Expansion of short-term faculty-led international immersion programs and classes will further internationalize PSU while building on the strengths of PSU's community-based learning model.

\section{A longer-term, more strategic focus.}

In collaboration with community partners, PSU identified the following four goals for future community-university partnerships; 1) develop long-term partnerships that withstand changes in institutional leadership, 2) establish a structure that provides transparency for current and potential community partners, 3) focus resources to achieve noticeable community-informed results, and 4) effectively measure and communicate results. PSU will focus efforts for building future community-university partnerships across all levels. This includes individual students and professors, departments or cohorts, and campus-wide policies and partnerships.

PSU's second (r)evolution provides unique opportunities to build on historical successes and develop innovative community engagement programs. This engaged learning and research environment allows PSU to leverage faculty and partner expertise while addressing community needs and provide students real-world learning opportunities.

\section{Community Environmental Services}

Community Environmental Services (CES) is a research and service unit within PSU's Center for Urban Studies in the Nohad A. Toulane School of Urban Studies and 
Planning that provides research, technical assistance, and educational outreach in the solid waste and recycling field (Portland State University, 2015a). CES contracts with various community partners to conduct quality, professional-level research and service, while providing undergraduate and graduate student employees opportunities to develop leadership and professional skills.

\section{History of the Organization}

Formed in 1989 by PSU professors, the Recycling Education Project (REP) was a class that surveyed residents in multifamily (apartment) buildings about their recycling practices. REP students then developed a plan to offer recycling equipment and education to multifamily communities and proposed a pilot program to the City of Portland, leading to the first multifamily recycling program in the country. Expanding on the success of the initial partnership with the City of Portland, REP students and faculty continued providing recycling education and assistance to other communities, governments, and private organizations in the Portland-metro area. In 1998, the organization was renamed "Community Environmental Services" to reflect the wider range of services provided. This change also aligned with the mission to provide students opportunities to develop leadership, professional job skills, and civic responsibility through education, service, and research addressing urban environmental issues (Community Environmental Services, 2003). Over the past 25 years, CES has employed more than 250 undergraduate and graduate students and worked with various community-based learning courses, including University Studies capstone 
classes. Since 1989, CES has worked with more than 150 community partners including local governments, non-profit organizations, and for-profit businesses providing a range of services. Twenty-five years of innovative and professional research and service has created a robust network of CES alumni and partners throughout the solid waste and materials management industry in the Portland-metro region.

\section{Organizational Structure}

As a research and service unit at PSU, CES provides high-quality research and technical expertise to local community partners through contracts and agreements. CES operates similar to a consulting firm, simultaneously managing multiple contracts with unique timelines. Three non-teaching faculty research assistants lead a staff of 20-30 undergraduate and graduate student employees who earn an hourly wage. In addition to student hourly wage positions, CES has multiple graduate research assistant positions that cover the cost of tuition and provide a monthly stipend.

Student positions and responsibilities vary depending on the project ranging from support staff to project lead. Support staff positions are ideal starting points for students, providing them with the industry specific knowledge and experiences that they can build upon. Support staff work on a variety of CES projects typically during the "boots on the ground" phase. This could include collecting data by hand-sorting garbage and collecting data such as material weights and observations about the materials in the stream. Support staff also provide educational outreach by speaking with local residents 
and businesses about their recycling system and making suggestions for improvements. Training and supervision of support staff is provided by project leads and CES faculty. Project lead positions have more responsibility than support staff and provide elements of project management. This includes ongoing communication with community partners providing regular project updates. Project leads manage support staff by providing training, scheduling, and supervision. Project leads are responsible for analyzing and interpreting data and then writing a report presenting the findings and providing recommendations. Project leads are typically students that have some professional experience and skills and can be undergraduate or graduate level. Graduate research assistance positions are similar to project leads but require students to be enrolled in a graduate program.

The different types of student employee positions allows for advancement as students become more experienced. Because the scope of work varies for each project, students can work on multiple projects providing support or as a project lead. CES faculty provide project scoping, development, and management while guiding and supervising student employees to ensure project partners are receiving high-quality professional research and services.

\section{Partnerships}

CES has continued to work with the City of Portland, providing recycling outreach and assistance to multifamily communities for nearly 25 years. Beginning in 1992, the City of Portland contracted with CES to collect data from curbside single-family 
residential waste that is used to set the residential hauling fees. In 2003 , the city began contracting with CES to provide management and assistance for the City of Portland Event Recycling Program that works with event planners around the city to provide recycling equipment and assistance to divert waste generated at events (Community Environmental Services, 2015a). In addition to these long-standing projects, CES has collaborated with the City of Portland on multiple outreach and data collection and analysis projects that have helped develop and evaluate city recycling programs and initiatives.

Other legacy partners that CES has been working with for over 10 years include Metro, the regional government, and the Port of Portland. CES has provided recycling outreach and assistance to multifamily communities and businesses throughout the region and worked with Metro to develop a residential recycling campaign to provide direct feedback to households about their recycling habits (Community Environmental Services, 2015c). The partnership with the Port of Portland is an innovative project that began in 2003 and provides operational assistance and support for all Port of Portland properties with a focus on Portland International Airport (PDX). A team of CES employees, based at the Port of Portland Headquarters at PDX, works directly with Port employees to oversee, design, and implement waste and materials management programs at the airport, marine terminals, and the headquarters building. This project provides students opportunities to develop innovative pilot programs and initiatives 
encouraging waste reduction that have contributed to the Port's role as a leader in sustainability (Community Environmental Services, 2015d; Port of Portland, 2014).

In addition to the legacy partners and project, CES has worked with a variety of partners to perform waste audits that provide a detailed analysis of material streams and the opportunities to increase waste prevention and diversion, reduce hauling costs, or to evaluate or meet sustainability goals (Community Environmental Services, 2015b).

\section{Curriculum Connection}

CES, at the time the Recycling Education Program, was created with a strong connection to urban studies and sustainability curriculum. However, as the organization evolved, the direct connection to PSU curriculum faded. Recently some connections with curriculum have occurred when CES faculty provide assistance to professors and classes as an industry and subject matter expert. CES involvement ranges from assisting professors during course development to working directly with students throughout the term. CES has worked with both undergraduate and graduate level classes in various academic programs.

For CES student employees, connecting project experiences to their education has been the responsibility of the individual and has depended on initiative from the student and his or her academic advisor. For certain academic programs, CES employees have been able to use their paid work experience as required internship or field credits. While this has provided CES student employees academic credit for their work, the 
curricular connections are relatively weak and the student and academic advisor were responsible for developing learning outcomes.

As CES operations' and PSU's commitment to sustainability and community partnerships are discussed, questions about the connection to key sustainability competencies arise. Are PSU students and CES student employees developing key sustainability competencies? If so, does PSU's engaged learning and research environment provide opportunities for those students to develop the competencies? Alternatively, does CES as an informal learning model facilitate competency development?

Existing literature provides evaluations of the effect of real-world learning opportunities in formal sustainability programs with a strong curricular connection (Steinemann, 2003; Brian \& Thomas, 2013; Brundiers, Wiek, \& Redman, 2010; Brundiers \& Wiek, 2011). There is also existing literature that evaluates formal sustainability programs and key sustainability competency development (Brundiers, Wiek, \& Redman, 2010) or skills that contribute to key sustainability competencies (Brian \& Thomas, 2013). One study conducted by Barth, Godmann, Rieckmann, and Stolenberg (2007), asks how key competencies can be realized by evaluating students in a formal sustainability program and students participating in informal sustainability activites hosted by the university. While this study found that sustainability competencies were developed by students in both the formal and informal settings, neither incorporated real-world learning or community engagement components. Research that evaluates 
the development of sustainability competencies through formal and informal real-world learning opportunites is needed.

The next chapter introduces the research specific to this study that focuses on the development of key sustainability competencies by CES alumni, and impacts on their employment opportunities post-graduation. 


\section{Chapter 3: Research Design and Findings}

Building on the sustainability competency literature and the hypothesized critical role of real-world learning, this research examines students' development of sustainability competencies through experiences working at CES or their academic program at PSU. Specifically, this research addresses the following questions:

1. At the time students left CES or PSU, how would they rate their level of proficiency in each of the key sustainability competencies.

2. To which would they attribute their level of competency development, experiences working at CES or their academic studies, or a combination of both.

3. Which did the students believe had more impact on their employability and career opportunities, working at CES, academic studies, or other influence. Through PSU's Declaration of Support for Sustainability, the university has established a goal to instill sustainability in all colleges, schools, and academic programs (Portland State University, 2013a). This research assumes that elements of sustainability are being incorporated into programs across campus to provide students with sustainability education curriculum. Because PSU has community-based learning components in all academic programs, this research assumes CES - as an informal learning model that does not have an associated curricular component - provides real-world learning in a sustainability context. This research hypothesizes that working at CES provided realworld learning opportunities students would not have experienced in their academic 
studies that led to the development of sustainability competencies and positively affected their employment post-graduation.

To address these questions, an online survey was distributed to CES alumni. The following sections include a description of the research methods, the survey results, and a discussion of the key findings that emerged from the research.

\section{Research Methods}

\section{Survey Development}

A survey was created and administered using Qualatrics, an online survey and research platform, assessing the development of key sustainability competencies by CES alumni. Wiek, Withycombe, and Redman (2011) identified key sustainability competencies, discussed in Chapter 1 . The survey contained multiple choice, short answer, and open-ended questions asking respondents to reflect on (1) their experiences working at CES, (2) their academic studies at PSU, and (3) their career opportunities after leaving CES or PSU. The survey included introductory questions to provide background information about each respondent's time at CES, including their academic program while at PSU. The full text of the Qualatrics survey is provided in the Appendix.

The introductory questions were followed by specific questions about each sustainability competency. A short description of each competency was provided and respondents were asked to rate their level of proficiency at the time they left CES or PSU by selecting an appropriate response - not proficient, somewhat proficient, or very 
proficient. Following each competency, respondents were asked to attribute their level of proficiency by selecting a response - working at CES, academic studies at PSU, or both equally. The final section of the survey asked respondents which had more of an impact on their employability and career opportunities - working at CES, academic studies, both equally, or other - followed by an open-ended question asking for further explanation of their selection. The combination of multiple choice and open-ended follow-up questions allowed survey respondents to select what they viewed as their most appropriate single response, while providing further insight about their selection.

\section{Survey Distribution}

Survey sample criteria screened for CES alumni who had been enrolled at PSU and employed by CES and had left PSU or CES prior to November 1, 2014. A list of alumni was provided by CES that included a range of personal contact information for employees from 1990 to November 2014. The total number of CES alumni who met the survey respondent criteria was 220; however, the survey was not directly distributed to all 220 former employees. While the provided CES alumni list was the most complete database available and had been managed by CES internally on a regular basis, the electronic contact information for many former employees was missing or out of date. Seventy-six (76) CES alumni did not have an email contact provided, while 85 had a PSUhosted email, and 87 employees had a personal email. A personal link for the survey was sent to 167 email addresses (for some employees both a personal and a PSU email address were used) of which 29 (17\%) were undeliverable. Because the CES alumni 
database did not have complete or updated email information for the survey respondent sample, the survey was also distributed using the Community Environmental Services LinkedIn group page and the Community Environmental Services Facebook page. Qualatrics prevented duplicate responses from those who received a personal link through the email and could save their progress; however, multiple responses were possible if survey respondents accessed the survey with multiple IP addresses through the link on Facebook and LinkedIn.

\section{Findings}

Reported survey results include the number of responses and a percent of the total responses for each question. A total of 65 surveys were submitted, $71 \%$ (46) were accessed through a personal link provided in a direct email while $29 \%$ (19) were opened through the link provided on the CES LinkedIn and Facebook page. Because respondents were not required to answer each question, the number of responses for each question varies. An inferential statistical analysis was not performed for this research.

\section{Competencies}

The following descriptions of the key sustainability competencies were provided and respondents were asked to select their level of proficiency (not, somewhat, and very) at the time they left CES or PSU.

- Systems-thinking competence is defined as the ability to analyze complex systems across different fields (environment, society, economy, etc.) and 
scales (local to global) while considering systemic features and problemsolving frameworks related to sustainability issues.

- Anticipatory competence is defined as the ability to analyze, evaluate, and articulate the long-term future of various sustainability issues, including unintended consequences and inter-generational equity.

- Normative competence is defined as the ability to convey, apply, and negotiate sustainability values, goals, and targets. This includes the ability to first assess the current issue and then the ability to create a more sustainable vision for that issue.

- Strategic competence is defined as the ability to "get things done" by designing and implementing interventions and transformative strategies toward improved sustainability. This requires familiarity with real-world situations and relationships, political understanding, power structures and relationships, ability to convey technical issues in layman's terms, and to meet deadlines.

- Interpersonal competence is defined as the ability to motivate, enable, and facilitate collaborative and participatory sustainability research and problem solving. This is the ability to understand, compare, and critically evaluate different positions, perspectives, and preferences.

Table 3.1, next page, provides the response rate for each competency. 


\begin{tabular}{l|ccc} 
& $\begin{array}{c}\text { NOT } \\
\text { PROFICIENT }\end{array}$ & $\begin{array}{c}\text { SOMEWHAT } \\
\text { PROFICIENT }\end{array}$ & $\begin{array}{c}\text { VERY } \\
\text { PROFICIENT }\end{array}$ \\
\hline SYSTEMS-THINKING (N=52) & $4 \%$ & $44 \%$ & $52 \%$ \\
ANTICIPATORY $(\mathrm{N}=52)$ & $13 \%$ & $54 \%$ & $33 \%$ \\
NORMATIVE $(\mathrm{N}=51)$ & $4 \%$ & $43 \%$ & $53 \%$ \\
STRATEGIC $(\mathrm{N}=51)$ & $10 \%$ & $27 \%$ & $63 \%$ \\
INTERPERSONAL $(\mathrm{N}=51)$ & $4 \%$ & $31 \%$ & $65 \%$
\end{tabular}

Table 3.1: Sustainability competency proficiency level reported by CES alumni.

For all competencies, except for anticipatory, the majority of the responses were very proficient (ranging from $52 \%$ of the responses to $65 \%$ ). The only competency that had more than $10 \%$ of not proficient responses was strategic (10\%) and anticipatory $(13 \%)$; this was also the only competency that a majority of the responses was somewhat proficient (54\%).

If respondents selected somewhat proficient or very proficient, they were asked if they would attribute their level of proficiency to working at CES, their academic studies, or both equally. If respondents selected not proficient they were directed to the next competency or section of the survey. Table 3.2 below shows the responses for perceived sources of competencies.

\begin{tabular}{l|ccc}
\multicolumn{1}{c}{ CES } & ACADEMIC & BOTH EQUALLY \\
\hline SYSTEMS-THINKING $(\mathrm{N}=50)$ & $12 \%$ & $28 \%$ & $60 \%$ \\
ANTICIPATORY $(\mathrm{N}=44)$ & $23 \%$ & $25 \%$ & $52 \%$ \\
NORMATIVE $(\mathrm{N}=49)$ & $27 \%$ & $18 \%$ & $55 \%$ \\
STRATEGIC $(\mathrm{N}=46)$ & $39 \%$ & $7 \%$ & $54 \%$ \\
INTERPERSONAL $(\mathrm{N}=48)$ & $25 \%$ & $13 \%$ & $63 \%$
\end{tabular}

Table 3.2: Attributed competency development of CES alumni.

The majority of respondents attributed their level of proficiency for each competency to both CES and academic studies equally (ranging from 52\% of the responses to 63\%). The competencies with the highest academic response rate was systems-thinking (28\%) and 
anticipatory (25\%). Normative (27\%), strategic (39\%), and interpersonal $(25 \%)$ had the highest response rate for working at CES.

To further analyze the survey results, the responses were sorted by academic program. From the 65 submitted surveys, 54 completed the sections about sustainability competency development. Within those 54 surveys, $61 \%$ of the respondents were enrolled in a graduate program and $15 \%$ were working on an undergraduate degree. Six percent (6\%) graduated from an undergraduate program and enrolled in a graduate program while at CES and $19 \%$ did not indicate whether their program was graduate or undergraduate level. Respondents were enrolled in 22 different degree programs in six different colleges at PSU. There was also one response that did not specify a degree and one that was working on a dual degree in different colleges. Table 3.3, next page, provides the number of survey respondents for each academic program and college. 


\begin{tabular}{|c|c|c|}
\hline COLLEGE & ACADEMIC DEGREE & LEVEL OF DEGREE \\
\hline \multirow{8}{*}{$\begin{array}{l}\text { College of Urban \& } \\
\text { Public Affairs (36) }\end{array}$} & Community Development (3) & Undergraduate \\
\hline & $\begin{array}{l}\text { Community Development/Masters of } \\
\text { Urban and Regional Planning (1) }\end{array}$ & $\begin{array}{l}\text { Undergraduate then } \\
\text { graduate }\end{array}$ \\
\hline & $\begin{array}{l}\text { Masters of Urban and Regional } \\
\text { Planning (12) }\end{array}$ & Graduate \\
\hline & Masters of Public Administration (7) & Graduate \\
\hline & Political Science (2) & $\begin{array}{l}\text { Undergraduate (1), } \\
\text { unsure (1) }\end{array}$ \\
\hline & $\begin{array}{l}\text { Political Science/Masters of Public } \\
\text { Administration (1) }\end{array}$ & $\begin{array}{l}\text { Undergraduate then } \\
\text { graduate }\end{array}$ \\
\hline & Real Estate Development (1) & Graduate \\
\hline & Urban Studies (9) & Graduate \\
\hline \multirow{7}{*}{$\begin{array}{l}\text { College of Liberal Arts } \\
\text { \& Sciences (10) }\end{array}$} & Biology (1) & Unsure \\
\hline & Earth Science (1) & Undergraduate \\
\hline & $\begin{array}{l}\text { Environmental Science \& Management } \\
\text { (2) }\end{array}$ & Graduate \\
\hline & Environmental Studies (3) & Unsure \\
\hline & $\begin{array}{l}\text { Environmental Studies and Geography } \\
\text { (1) }\end{array}$ & Unsure \\
\hline & History (1) & Unsure \\
\hline & International Studies (1) & Undergraduate \\
\hline \multirow{3}{*}{ College of the Arts (3) } & Architecture (1) & Undergraduate \\
\hline & Masters in Arts (1) & Graduate \\
\hline & Theater Arts (1) & Unsure \\
\hline $\begin{array}{l}\text { Graduate School of } \\
\text { Education (1) }\end{array}$ & $\begin{array}{l}\text { Leadership for Sustainability Education } \\
\text { (1) }\end{array}$ & Graduate \\
\hline $\begin{array}{l}\text { Maseeh College of } \\
\text { Engineering \& } \\
\text { Computer Science (1) }\end{array}$ & Civil and Environmental Engineering (1) & $\begin{array}{l}\text { Undergraduate then } \\
\text { graduate }\end{array}$ \\
\hline $\begin{array}{l}\text { School of Business } \\
\text { Administration (1) }\end{array}$ & Business Management (1) & Undergraduate \\
\hline \multirow{2}{*}{$\begin{array}{l}\text { No degree or multiple } \\
\text { colleges ( } 2 \text { ) }\end{array}$} & Degree not specified (1) & -- \\
\hline & Sociology and Computer Science (1) & Unsure \\
\hline
\end{tabular}

Table 3.3: Survey responses by college, academic degree, and level.

\section{Level of Academic Program}

Survey responses were first sorted by level of academic program, which included responses from 33 graduates, eight (8) undergraduates, three (3) CES alumni who began as an undergrad and then started a graduate program, and ten (10) individuals who did 
not specify a program. Table 3.4 below provides the level of proficiency for each competency that CES alumni felt they developed, sorted by level of academic program.

\begin{tabular}{|c|c|c|c|c|c|}
\hline & Systems-thinking & Anticipatory & Normative & Strategic & Interpersonal \\
\hline \multicolumn{6}{|c|}{ GRADUATE $(\mathrm{N}=33)$} \\
\hline Not & $0 \%$ & $15 \%$ & $3 \%$ & $12 \%$ & $3 \%$ \\
\hline Somewhat & $52 \%$ & $55 \%$ & $48 \%$ & $21 \%$ & $33 \%$ \\
\hline Very & $48 \%$ & $30 \%$ & $48 \%$ & $67 \%$ & $64 \%$ \\
\hline \multicolumn{6}{|c|}{ UNDERGRADUATE $(\mathrm{N}=8)$} \\
\hline Not & $13 \%$ & $25 \%$ & $13 \%$ & $0 \%$ & $13 \%$ \\
\hline Somewhat & $25 \%$ & $38 \%$ & $25 \%$ & $50 \%$ & $25 \%$ \\
\hline Very & $63 \%$ & $38 \%$ & $63 \%$ & $50 \%$ & $63 \%$ \\
\hline \multicolumn{6}{|c|}{ UNDERGRADUATE THEN GRADUATE $(\mathrm{N}=3)$} \\
\hline Not & $0 \%$ & $33 \%$ & $0 \%$ & $0 \%$ & $0 \%$ \\
\hline Somewhat & $67 \%$ & $33 \%$ & $33 \%$ & $33 \%$ & $33 \%$ \\
\hline Very & $33 \%$ & $33 \%$ & $67 \%$ & $67 \%$ & $67 \%$ \\
\hline \multicolumn{6}{|c|}{ UNSURE $(\mathrm{N}=10)$} \\
\hline Not & $0 \%$ & $0 \%$ & $0 \%$ & $10 \%$ & $0 \%$ \\
\hline Somewhat & $30 \%$ & $60 \%$ & $30 \%$ & $20 \%$ & $20 \%$ \\
\hline Very & $70 \%$ & $40 \%$ & $70 \%$ & $70 \%$ & $80 \%$ \\
\hline
\end{tabular}

Table 3.4: Sustainability competency proficiency level reported by CES alumni, sorted by academic degree level.

A majority of the responses from graduate students reported a very proficient level for strategic (67\%) and interpersonal (64\%) competencies and felt somewhat proficient in systems-thinking (52\%) and anticipatory (55\%). The only competency that all graduate students felt they developed some level of proficiency (somewhat or very proficient) was systems-thinking. A majority of the respondents enrolled in undergraduate programs reported feeling very proficient in systems-thinking (63\%), normative (63\%), and interpersonal (63\%) competencies. Every competency had some respondents who felt they were not proficient (ranging from $13 \%$ to $25 \%$ ) except for strategic. For students who competed an undergraduate degree and then began a graduate program while at CES, respondents felt they were very proficient in normative 
(67\%), strategic (67\%), and interpersonal (67\%) competencies. The only competencies where respondents felt they were not proficient was anticipatory (33\%), all others reported some level of proficiency (some or very). For the respondents where the level of academic degree could not be determined, the majority felt very competent in all competencies except for anticipatory (majority felt somewhat proficient, $60 \%$ ). The only competency that respondents reported feeling not proficient was strategic (10\%).

By analyzing the reported level of proficiency of each sustainability competency by the level of academic degree, the findings show that across all levels of degrees the majority of respondents felt they were very proficient in normative, strategic, and interpersonal competencies. Respondents enrolled in undergraduate programs were the only ones that felt not proficient in systems-thinking (13\%). Respondents across all other levels of academic program reported some level of proficiency.

Table 3.5, next page, utilizes the same levels of academic degree to analyze how CES alumni would attribute their development of each sustainability competency. 


\begin{tabular}{|c|c|c|c|c|c|}
\hline & Systems-thinking & Anticipatory & Normative & Strategic & Interpersonal \\
\hline \multicolumn{6}{|c|}{ GRADUATE (N=33) } \\
\hline CES & $6 \%$ & $19 \%$ & $25 \%$ & $41 \%$ & $19 \%$ \\
\hline Academic & $30 \%$ & $33 \%$ & $25 \%$ & $7 \%$ & $13 \%$ \\
\hline Both Equally & $64 \%$ & $48 \%$ & $50 \%$ & $52 \%$ & $68 \%$ \\
\hline \multicolumn{6}{|c|}{ UNDERGRADUATE $(\mathrm{N}=7)$} \\
\hline CES & $29 \%$ & $50 \%$ & $29 \%$ & $38 \%$ & $14 \%$ \\
\hline Academic & $29 \%$ & $17 \%$ & $0 \%$ & $13 \%$ & $14 \%$ \\
\hline Both Equally & $43 \%$ & $33 \%$ & $71 \%$ & $50 \%$ & $71 \%$ \\
\hline \multicolumn{6}{|c|}{ UNDERGRADUATE THEN GRADUATE $(\mathrm{N}=3)$} \\
\hline CES & $0 \%$ & $0 \%$ & $67 \%$ & $0 \%$ & $33 \%$ \\
\hline Academic & $0 \%$ & $0 \%$ & $0 \%$ & $0 \%$ & $0 \%$ \\
\hline Both Equally & $100 \%$ & $100 \%$ & $33 \%$ & $100 \%$ & $67 \%$ \\
\hline \multicolumn{6}{|c|}{ UNSURE $(\mathrm{N}=10)$} \\
\hline CES & $20 \%$ & $20 \%$ & $20 \%$ & $44 \%$ & $50 \%$ \\
\hline Academic & $20 \%$ & $10 \%$ & $10 \%$ & $0 \%$ & $10 \%$ \\
\hline Both Equally & $60 \%$ & $70 \%$ & $70 \%$ & $56 \%$ & $40 \%$ \\
\hline
\end{tabular}

Table 3.5: Attributed competency development of CES alumni by level of academic program.

Echoing the aggregated results presented in the beginning of this section, a

majority of respondents attribute their development of sustainability competencies to their experiences working at CES and academic programs both equally. Respondents enrolled in an undergraduate degree attributed CES work and academic studies both equally for all competencies except anticipatory, which the majority attributed to CES (50\%). Similarly, a majority of CES alumni who went from an undergraduate to graduate level program attributed their development of all competencies to CES and academics both equally except for normative, which a majority attributed to CES (67\%). These respondents also attributed their development for each competency to experiences working at CES or CES and academic studies both equally, and there were no responses attributing development solely to academic studies. A Majority of respondents where the level of academic program was not specified attributed their proficiency of 
interpersonal competency to experiences working at CES (50\%) while all other

competencies were attributed to CES and academic studies both equally.

\section{Specific College or School}

In addition to sorting survey responses by level of academic program, Table 3.6

below provides the level of proficiency reported by survey respondents sorted by the college or school that houses their academic program.

\begin{tabular}{|c|c|c|c|c|c|}
\hline \multicolumn{2}{|r|}{ Systems-thinking } & Anticipatory & Normative & Strategic & Interpersonal \\
\hline \multicolumn{6}{|c|}{ COLLEGE OF URBAN \& PUBLIC AFFAIRS $(\mathrm{N}=36)$} \\
\hline Not & $3 \%$ & $19 \%$ & $6 \%$ & $8 \%$ & $6 \%$ \\
\hline Somewhat & $44 \%$ & $42 \%$ & $44 \%$ & $22 \%$ & $28 \%$ \\
\hline Very & $53 \%$ & $39 \%$ & $50 \%$ & $69 \%$ & $67 \%$ \\
\hline \multicolumn{6}{|c|}{ COLLEGE OF LIBERAL ARTS \& SCIENCES $(\mathrm{N}=10)$} \\
\hline Not & $0 \%$ & $0 \%$ & $0 \%$ & $0 \%$ & $0 \%$ \\
\hline Somewhat & $30 \%$ & $70 \%$ & $20 \%$ & $10 \%$ & $20 \%$ \\
\hline Very & $70 \%$ & $30 \%$ & $80 \%$ & $90 \%$ & $80 \%$ \\
\hline \multicolumn{6}{|c|}{ COLLEGE OF THE ARTS ( $\mathrm{N}=3$ ) } \\
\hline Not & $0 \%$ & $33 \%$ & $0 \%$ & $33 \%$ & $0 \%$ \\
\hline Somewhat & $67 \%$ & $67 \%$ & $67 \%$ & $67 \%$ & $33 \%$ \\
\hline Very & $33 \%$ & $0 \%$ & $33 \%$ & $0 \%$ & $67 \%$ \\
\hline \multicolumn{6}{|c|}{ GRADUATE SCHOOL OF EDUCATION (N=1) } \\
\hline Not & $0 \%$ & $0 \%$ & $0 \%$ & $0 \%$ & $0 \%$ \\
\hline Somewhat & $0 \%$ & $100 \%$ & $0 \%$ & $100 \%$ & $100 \%$ \\
\hline Very & $100 \%$ & $0 \%$ & $100 \%$ & $0 \%$ & $0 \%$ \\
\hline \multicolumn{6}{|c|}{ MASEEH COLLEGE OF ENGINEERING \& COMPUTER SCIENCE ( $N=1)$} \\
\hline Not & $0 \%$ & $0 \%$ & $0 \%$ & $0 \%$ & $0 \%$ \\
\hline Somewhat & $100 \%$ & $100 \%$ & $100 \%$ & $100 \%$ & $100 \%$ \\
\hline Very & $0 \%$ & $0 \%$ & $0 \%$ & $0 \%$ & $0 \%$ \\
\hline \multicolumn{6}{|c|}{ SCHOOL OF BUSINESS ADMINISTRATION ( $\mathrm{N}=1)$} \\
\hline Not & $0 \%$ & $0 \%$ & $0 \%$ & $0 \%$ & $0 \%$ \\
\hline Somewhat & $100 \%$ & $100 \%$ & $0 \%$ & $100 \%$ & $0 \%$ \\
\hline Very & $0 \%$ & $0 \%$ & $100 \%$ & $0 \%$ & $100 \%$ \\
\hline \multicolumn{6}{|c|}{ NO PROGRAM, MULTIPLE COLLEGES (N=2) } \\
\hline Not & $0 \%$ & $0 \%$ & $0 \%$ & $50 \%$ & $0 \%$ \\
\hline Somewhat & $50 \%$ & $50 \%$ & $50 \%$ & $0 \%$ & $50 \%$ \\
\hline Very & $50 \%$ & $50 \%$ & $50 \%$ & $50 \%$ & $50 \%$ \\
\hline
\end{tabular}

Table 3.6: Sustainability competency proficiency level reported by CES alumni, sorted by college and school. 
A majority of students enrolled in the College of Urban and Public Affairs programs reported being very proficient in normative (50\%), strategic (69\%), and interpersonal (67\%) competencies. Survey respondents enrolled in programs in the College of Liberal Arts and Sciences reported some level of proficiency (somewhat or very proficient) in all sustainability competencies. A majority of respondents enrolled in programs in the College of the Arts felt they were somewhat proficient in all competencies.

Across all colleges and schools, with the exception of the College of Urban and Public Affairs, 0\% of respondents felt they were not proficient in systems-thinking, normative, and interpersonal competencies. The percent of students in programs in the College of Urban and Public Affairs who felt they were not proficient in each competency was minimal, ranging from $3 \%$ to $8 \%$, except for anticipatory which $19 \%$ of respondents felt they were not proficient.

Table 3.7, next page, analyzes how CES alumni would attribute their development of each sustainability competency, sorted by college or school. 
Systems-thinking $\mid$ Anticipatory $\mid$ Normative Strategic $\mid$ Interpersonal COLLEGE OF URBAN \& PUBLIC AFFAIRS $(\mathrm{N}=35)$

\begin{tabular}{|c|c|c|c|c|c|}
\hline \\
\hline CES & $9 \%$ & $18 \%$ & $21 \%$ & $36 \%$ & $21 \%$ \\
\hline Academic & $26 \%$ & $25 \%$ & $21 \%$ & $6 \%$ & $12 \%$ \\
\hline Both Equally & $66 \%$ & $57 \%$ & $59 \%$ & $58 \%$ & $67 \%$ \\
\hline \multicolumn{6}{|c|}{ COLLEGE OF LIBERAL ARTS \& SCIENCES $(\mathrm{N}=10)$} \\
\hline CES & $0 \%$ & $10 \%$ & $10 \%$ & $20 \%$ & $30 \%$ \\
\hline Academic & $40 \%$ & $30 \%$ & $10 \%$ & $10 \%$ & $20 \%$ \\
\hline Both Equally & $60 \%$ & $60 \%$ & $80 \%$ & $70 \%$ & $50 \%$ \\
\hline \multicolumn{6}{|c|}{ COLLEGE OF THE ARTS ( $\mathrm{N}=3$ ) } \\
\hline CES & $33 \%$ & $100 \%$ & $100 \%$ & $100 \%$ & $33 \%$ \\
\hline Academic & $0 \%$ & $0 \%$ & $0 \%$ & $0 \%$ & $0 \%$ \\
\hline Both Equally & $67 \%$ & $0 \%$ & $0 \%$ & $0 \%$ & $67 \%$ \\
\hline \multicolumn{6}{|c|}{ GRADUATE SCHOOL OF EDUCATION (N=1) } \\
\hline CES & $0 \%$ & $0 \%$ & $0 \%$ & $100 \%$ & $0 \%$ \\
\hline Academic & $0 \%$ & $100 \%$ & $0 \%$ & $0 \%$ & $0 \%$ \\
\hline Both Equally & $100 \%$ & $0 \%$ & $100 \%$ & $0 \%$ & $100 \%$ \\
\hline \multicolumn{6}{|c|}{ MASEEH COLLEGE OF ENGINEERING \& COMPUTER SCIENCE ( $N=1)$} \\
\hline CES & $0 \%$ & $0 \%$ & $100 \%$ & $0 \%$ & $100 \%$ \\
\hline Academic & $0 \%$ & $0 \%$ & $0 \%$ & $0 \%$ & $0 \%$ \\
\hline Both Equally & $100 \%$ & $100 \%$ & $0 \%$ & $100 \%$ & $0 \%$ \\
\hline \multicolumn{6}{|c|}{ SCHOOL OF BUSINESS ADMINISTRATION ( $\mathrm{N}=1$ ) } \\
\hline CES & $100 \%$ & $100 \%$ & $100 \%$ & $100 \%$ & $0 \%$ \\
\hline Academic & $0 \%$ & $0 \%$ & $0 \%$ & $0 \%$ & $0 \%$ \\
\hline Both Equally & $0 \%$ & $0 \%$ & $0 \%$ & $0 \%$ & $100 \%$ \\
\hline \multicolumn{6}{|c|}{ NO PROGRAM, MULTIPLE COLLEGES $(\mathrm{N}=2)$} \\
\hline CES & $50 \%$ & $50 \%$ & $50 \%$ & $100 \%$ & $50 \%$ \\
\hline Academic & $50 \%$ & $0 \%$ & $50 \%$ & $0 \%$ & $0 \%$ \\
\hline Both Equally & $0 \%$ & $50 \%$ & $0 \%$ & $0 \%$ & $50 \%$ \\
\hline
\end{tabular}

Table 3.7: Attributed competency development of CES alumni by college and school.

Responses from students enrolled in programs in the College of Liberal Arts and

Sciences and the College of Urban and Public Affairs reiterate the findings from the aggregated data that shows the development of all competencies was attributed to experiences working at CES and academic studies both equally. Respondents enrolled in programs in the College of the Arts only attributed their development of competencies to CES or CES and their academic program both equally. 


\section{College of Urban and Public Affairs}

Because $67 \%$ of all survey respondents were enrolled in degrees in the College of Urban and Public Affairs, the individual degree programs were sorted for further analysis.

Twenty-two percent (22\%) of all survey respondents were Masters of Urban and Regional Planning students, $17 \%$ were Urban Studies students, and 13\% were enrolled in the Masters of Public Administration program. Table 3.8 (next page) provides the level of proficiency for each competency that CES alumni felt they developed, sorted by the academic program within the College of Urban and Public Affairs. 


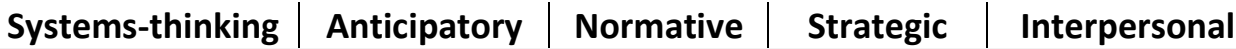
MASTERS OF URBAN AND REGIONAL PLANNING $(\mathrm{N}=12)$

\begin{tabular}{|c|c|c|c|c|c|}
\hline Not & $0 \%$ & $25 \%$ & $8 \%$ & $17 \%$ & $8 \%$ \\
\hline Somewhat & $50 \%$ & $50 \%$ & $50 \%$ & $17 \%$ & $42 \%$ \\
\hline Very & $50 \%$ & $25 \%$ & $42 \%$ & $67 \%$ & $50 \%$ \\
\hline \multicolumn{6}{|c|}{ URBAN STUDIES (MUS \& PHD) (N=9) } \\
\hline Not & $0 \%$ & $11 \%$ & $0 \%$ & $11 \%$ & $0 \%$ \\
\hline Somewhat & $33 \%$ & $33 \%$ & $56 \%$ & $22 \%$ & $11 \%$ \\
\hline Very & $67 \%$ & $56 \%$ & $44 \%$ & $67 \%$ & $89 \%$ \\
\hline \multicolumn{6}{|c|}{ MASTERS OF PUBLIC ADMINISTRATION ( $\mathrm{N}=7$ ) } \\
\hline Not & $0 \%$ & $14 \%$ & $0 \%$ & $0 \%$ & $0 \%$ \\
\hline Somewhat & $86 \%$ & $71 \%$ & $57 \%$ & $29 \%$ & $29 \%$ \\
\hline Very & $14 \%$ & $14 \%$ & $43 \%$ & $71 \%$ & $71 \%$ \\
\hline \multicolumn{6}{|c|}{ COMMUNITY DEVELOPMENT ( $\mathrm{N}=3$ ) } \\
\hline Not & $0 \%$ & $0 \%$ & $0 \%$ & $0 \%$ & $0 \%$ \\
\hline Somewhat & $0 \%$ & $33 \%$ & $33 \%$ & $33 \%$ & $33 \%$ \\
\hline Very & $100 \%$ & $67 \%$ & $67 \%$ & $67 \%$ & $67 \%$ \\
\hline \multicolumn{6}{|c|}{ POLITICAL SCIENCE (N=2) } \\
\hline Not & $50 \%$ & $50 \%$ & $50 \%$ & $0 \%$ & $50 \%$ \\
\hline Somewhat & $0 \%$ & $0 \%$ & $0 \%$ & $50 \%$ & $0 \%$ \\
\hline Very & $50 \%$ & $50 \%$ & $50 \%$ & $50 \%$ & $50 \%$ \\
\hline \multicolumn{6}{|c|}{ COMMUNITY DEVELOPMENT/MASTERS OF URBAN AND REGIONAL PLANNING $(\mathrm{N}=1)$} \\
\hline Not & $0 \%$ & $100 \%$ & $0 \%$ & $0 \%$ & $0 \%$ \\
\hline Somewhat & $100 \%$ & $0 \%$ & $0 \%$ & $0 \%$ & $0 \%$ \\
\hline Very & $0 \%$ & $0 \%$ & $100 \%$ & $100 \%$ & $100 \%$ \\
\hline \multicolumn{6}{|c|}{ REAL ESTATE DEVELOPMENT ( $\mathrm{N}=1)$} \\
\hline Not & $0 \%$ & $0 \%$ & $0 \%$ & $0 \%$ & $0 \%$ \\
\hline Somewhat & $0 \%$ & $0 \%$ & $0 \%$ & $0 \%$ & $100 \%$ \\
\hline Very & $100 \%$ & $100 \%$ & $100 \%$ & $100 \%$ & $0 \%$ \\
\hline
\end{tabular}

Table 3.8: Sustainability competency proficiency level reported by CES alumni, sorted by academic program in the College of Public and Urban Affairs.

A majority of Masters of Urban and Regional Planning students reported feeling very proficient in all competencies except anticipatory and normative, which a majority felt somewhat proficient. Each competency, except systems-thinking, had respondents who felt they were not proficient ranging from $8 \%$ (normative and interpersonal) to $25 \%$ (anticipatory) of the responses. A majority of the respondents in the Urban Studies program felt they were very proficient in all competencies except normative (somewhat 
proficient). The only competencies which respondents reported feeling not proficient were anticipatory (11\%) and strategic (11\%). A majority of the Masters of Public Administration respondents reported being somewhat proficient in all competencies except for strategic and interpersonal, in which a majority of respondents felt very proficient.

All academic programs reported some level (somewhat or very) of proficiency in systems-thinking except for one Political Science respondent.

Table 3.9 (next page) analyzes the same responses from academic programs within the College of Urban and Public Affairs to determine how CES alumni would attribute their development of each sustainability competency. 
Systems-thinking $\mid$ Anticipatory $\mid$ Normative $\mid$ Strategic $\mid$ Interpersonal MASTERS OF URBAN AND REGIONAL PLANNING ( $\mathrm{N}=12$ )

\begin{tabular}{|c|c|c|c|c|c|}
\hline & & & & & \\
\hline CES & $8 \%$ & $22 \%$ & $18 \%$ & $30 \%$ & $0 \%$ \\
\hline Academic & $25 \%$ & $22 \%$ & $36 \%$ & $10 \%$ & $27 \%$ \\
\hline Both Equally & $67 \%$ & $56 \%$ & $45 \%$ & $60 \%$ & $73 \%$ \\
\hline \multicolumn{6}{|c|}{ URBAN STUDIES (MUS \& PHD) (N=9) } \\
\hline CES & $11 \%$ & $13 \%$ & $11 \%$ & $50 \%$ & $22 \%$ \\
\hline Academic & $56 \%$ & $50 \%$ & $22 \%$ & $13 \%$ & $0 \%$ \\
\hline Both Equally & $33 \%$ & $38 \%$ & $67 \%$ & $38 \%$ & $78 \%$ \\
\hline \multicolumn{6}{|c|}{ MASTERS OF PUBLIC ADMINISTRATION (N=7) } \\
\hline CES & $0 \%$ & $20 \%$ & $43 \%$ & $57 \%$ & $67 \%$ \\
\hline Academic & $14 \%$ & $20 \%$ & $14 \%$ & $0 \%$ & $17 \%$ \\
\hline Both Equally & $86 \%$ & $60 \%$ & $43 \%$ & $43 \%$ & $17 \%$ \\
\hline \multicolumn{6}{|c|}{ COMMUNITY DEVELOPMENT $(\mathrm{N}=3)$} \\
\hline CES & $33 \%$ & $33 \%$ & $0 \%$ & $33 \%$ & $33 \%$ \\
\hline Academic & $0 \%$ & $0 \%$ & $0 \%$ & $0 \%$ & $0 \%$ \\
\hline Both Equally & $67 \%$ & $67 \%$ & $100 \%$ & $67 \%$ & $67 \%$ \\
\hline \multicolumn{6}{|c|}{ POLITICAL SCIENCE (N=2) } \\
\hline CES & $50 \%$ & $50 \%$ & $50 \%$ & $0 \%$ & $50 \%$ \\
\hline Academic & $0 \%$ & $0 \%$ & $0 \%$ & $50 \%$ & $0 \%$ \\
\hline Both Equally & $50 \%$ & $50 \%$ & $50 \%$ & $50 \%$ & $50 \%$ \\
\hline \multicolumn{6}{|c|}{ COMMUNITY DEVELOPMENT/MASTERS OF URBAN AND REGIONAL PLANNING ( $N=1)$} \\
\hline CES & $0 \%$ & -- & $100 \%$ & $0 \%$ & $0 \%$ \\
\hline Academic & $0 \%$ & -- & $0 \%$ & $0 \%$ & $0 \%$ \\
\hline Both Equally & $100 \%$ & -- & $0 \%$ & $100 \%$ & $100 \%$ \\
\hline \multicolumn{6}{|c|}{ REAL ESTATE DEVELOPMENT ( $\mathrm{N}=1)$} \\
\hline CES & $0 \%$ & $0 \%$ & $0 \%$ & $0 \%$ & $0 \%$ \\
\hline Academic & $0 \%$ & $0 \%$ & $0 \%$ & $0 \%$ & $100 \%$ \\
\hline Both Equally & $100 \%$ & $100 \%$ & $100 \%$ & $100 \%$ & $0 \%$ \\
\hline
\end{tabular}

Table 3.9: Attributed competency development by program in the College of Urban and Public Affairs.

A majority of the Masters of Urban and Regional Planning respondents attributed their development of all competencies to CES and their academic studies both equally. The majority of the responses for Urban Studies students varied by competency; systemsthinking and anticipatory were attributed to academics, strategic was attributed to CES, and normative and interpersonal were attributed to working at CES and their academic program both equally. A majority of Masters of Public Administration students 
attributed their development of systems-thinking and anticipatory competencies to working at CES and academic studies both equally. Strategic and interpersonal competencies were attributed to working at CES, while normative was attributed evenly to working at CES (43\%) and working at CES and academic studies both equally (43\%).

The survey findings discussed so far indicate that the majority of CES alumni felt they developed some level of proficiency for each of the key sustainability competencies, and would attribute that to working at CES and their academic studies both equally. Disaggregating the responses by academic level and college provided a more granular analysis showing the differences between the level of proficiency for each competency. While proficiency levels are based on self-assessments, the findings can be used to reflect on competency development in programs within each college and through CES operations.

\section{Career and Employment Opportunities}

After questions about the competencies, respondents were asked if there were skills, knowledge, or abilities not mentioned that they developed during their time working at CES and during their academic studies. This allowed respondents to provide personal insight about their time working at CES and their academic studies that may not have been covered by the competencies identified in the literature. There were 79 additional skills, combined into 23 categories, that respondents reported they developed through experiences working with CES. There were 47 additional skills attributed to academic studies that were combined into 26 categories. Table 3.10 below 
provides the reported additional skills and knowledge, as well as the percent of

responses for each.

\begin{tabular}{l|l} 
Developed While Working at CES (N=79) & Developed Through Academic Studies (N=47) \\
\hline Project management skills (13\%) & Theoretical background (13\%) \\
Professional development (9\%) & Data analysis and reporting (13\%) \\
Data analysis and reporting (8\%) & Collaboration (11\%) \\
Communication skills (8\%) & Research skills (9\%) \\
Specific computer program skills (8\%) & Equity and cultural competencies (4\%) \\
Industry knowledge (8\%) & Writing skills (4\%) \\
Networking (8\%) & Technical knowledge (4\%) \\
Exposure to local policies (8\%) & Presentation skills (4\%) \\
Collaboration (6\%) & Survey writing (2\%) \\
Outreach skills (5\%) & Time management (2\%) \\
Confidence (4\%) & Stakeholder mapping (2\%) \\
Project development (3\%) & Local government policies (2\%) \\
Employee management (3\%) & Community based social marketing (2\%) \\
Business processes (1\%) & Organizing meetings (2\%) \\
Leadership skills (1\%) & Leadership skills (2\%) \\
Familiarity with various institutional & Negotiation skills (2\%) \\
platforms (1\%) & Facilitation skills (2\%) \\
Technical writing (1\%) & Communication skills (2\%) \\
Contract development (1\%) & Graphic design skills (2\%) \\
Organization skills (1\%) & Consensus building (2\%) \\
Putting theories into practice (1\%) & Project management (2\%) \\
Partnership development (1\%) & Specific computer program skills (2\%) \\
Time management (1\%) & Public speaking (2\%) \\
Presentation skills (1\%) & Critical thinking (2\%) \\
& Networking (2\%) \\
\hline
\end{tabular}

Table 3.10: Additional skills and knowledge.

In addition to asking respondents about specific competency development, they were asked to identify which had more impact on their employment and career opportunities - working at CES, academic studies, both equally, or another source. Out of the 54 responses, $39 \%$ felt working at CES had more of an impact on their career opportunities, while 35\% felt CES and their academic studies both equally had the greatest impact. Thirteen percent (13\%) felt their academic studies had the greatest 
impact on their employability, while $13 \%$ felt that their employability and career opportunities were most impacted by another source. Table 3.11 below provides the responses from CES alumni regarding which they felt had a greater impact on their career, sorted by level of academic program. Following is Table 3.12 that provides the responses sorted by the college or school, followed by Table 3.13 that provides the responses of CES alumni by degree in the College of Urban and Public Affairs.

\begin{tabular}{|c|c|c|c|c|}
\hline & CES & Academic & $\begin{array}{l}\text { Both } \\
\text { Equally }\end{array}$ & Other \\
\hline Graduate $(\mathrm{N}=33)$ & $36 \%$ & $18 \%$ & $30 \%$ & $15 \%$ \\
\hline Undergraduate $(\mathrm{N}=8)$ & $50 \%$ & $0 \%$ & $38 \%$ & $13 \%$ \\
\hline Undergrad then Graduate $(\mathrm{N}=3)$ & $0 \%$ & $33 \%$ & $67 \%$ & $0 \%$ \\
\hline Unsure $(\mathrm{N}=10)$ & $50 \%$ & $0 \%$ & $40 \%$ & $10 \%$ \\
\hline
\end{tabular}

Table 3.11: Reported impact on career opportunities by level of academic degree.

\begin{tabular}{l|cccc} 
& \multicolumn{3}{c}{ Both } \\
\hline College of Urban and Public Affairs (N=36) & $36 \%$ & $17 \%$ & $36 \%$ & $11 \%$ \\
College of Liberal Arts \& Sciences (N=10) & $40 \%$ & $0 \%$ & $30 \%$ & $30 \%$ \\
College of the Arts (N=3) & $67 \%$ & $0 \%$ & $33 \%$ & $0 \%$ \\
Graduate School of Education (N=1) & $100 \%$ & $0 \%$ & $0 \%$ & $0 \%$ \\
Maseeh College of Engineering \& Computer & $0 \%$ & $100 \%$ & $0 \%$ & $0 \%$ \\
Science (N=1) & $0 \%$ & $0 \%$ & $100 \%$ & $0 \%$ \\
School of Business Administration (N=1) & $50 \%$ & $0 \%$ & $50 \%$ & $0 \%$ \\
No program, multiple colleges (N=2) & & & &
\end{tabular}

Table 3.12: Reported impact on career opportunities by academic college or school.

\begin{tabular}{|c|c|c|c|c|}
\hline & CES & Academic & $\begin{array}{c}\text { Both } \\
\text { Equally }\end{array}$ & Other \\
\hline $\begin{array}{l}\text { Masters of Urban and Regional Planning } \\
(\mathrm{N}=12)\end{array}$ & $25 \%$ & $25 \%$ & $50 \%$ & $0 \%$ \\
\hline Urban Studies $(\mathrm{N}=9)$ & $33 \%$ & $22 \%$ & $22 \%$ & $22 \%$ \\
\hline Masters of Public Administration $(\mathrm{N}=8)$ & $57 \%$ & $14 \%$ & $14 \%$ & $14 \%$ \\
\hline Community Development $(n=3)$ & $67 \%$ & $0 \%$ & $33 \%$ & $0 \%$ \\
\hline Political Science $(\mathrm{N}=2)$ & $50 \%$ & $0 \%$ & $50 \%$ & $0 \%$ \\
\hline $\begin{array}{l}\text { Community Development/Masters of } \\
\text { Urban and Regional Planning }(\mathrm{N}=1)\end{array}$ & $0 \%$ & $0 \%$ & $100 \%$ & $0 \%$ \\
\hline Real Estate Development $(\mathrm{N}=1)$ & $0 \%$ & $0 \%$ & $0 \%$ & $100 \%$ \\
\hline
\end{tabular}

Table 3.13: Reported impact on career opportunities by academic degree in the College of Urban and Public Affairs. 
By disaggregating the data, additional details about the reported impact of each surfaced. A majority of respondents enrolled in an undergraduate program indicated their experiences working at CES were most impactful. Within that same population, $0 \%$ felt their academic program had the greatest impact. By academic college and school, majority of responses indicated working at CES or CES and academic studies both equally had the greatest impact on career opportunities. The only alumni who felt their academic studies had the greatest impact on employment opportunities were from alumni in the College of Urban and Public Affairs (17\%) and Maseeh College of Engineering and Computer Science (100\%). Within the College of Urban and Public Affairs, the impact on career opportunities varies by degree. A majority of the Urban Studies, Masters of Public Administration, and Community Development students felt their experiences working at CES had a greater impact on their career, while a majority of the Masters of Urban and Regional Planning students felt CES and their academic studies both equally had the most impact.

Respondents were asked to follow up the previous question with a brief explanation of how they felt their selection had an impact on their career opportunities. Responses were coded into 23 categories that included 11 categories responding to the influence of working at CES, 8 categories explaining the impact of academic studies, 3 categories of responses for other influences and 1 category for both CES and academic equally impacting. Table 3.14 (next page) provides the coded categories for the different reasons mentioned by respondents, as well as the response rate for each. 


\section{Impact on Employment and Career Opportunities ( $\mathbf{N = 7 0 )}$}

\section{CES}

Developed professional skills through real-world experiences (16\%)

Networking opportunities (14\%)

Post-graduation employment determined because of CES position (7\%)

Project management experience (6\%)

Exposure to industry and local government professionals (4\%)

Reputation in the industry (4\%)

Experience managing staff (3\%)

Facilitated continued employment within PSU (1\%)

Influenced academic studies (1\%)

Influenced career path (1\%)

Provided outreach experience (1\%)

\section{ACADEMIC}

Degree desired for profession (10\%)

Degree provided background knowledge (10\%)

Degree provides advantage over peers (3\%)

Academic studies influenced career path (1\%)

Degree more impactful in non-sustainability field (1\%)

Degree provided real world experience (1\%)

Developed critical thinking skills (1\%)

\section{OTHER}

Previous employment had a greater impact (7\%)

Dissertation work more beneficial (1\%)

Both CES and PSU had an impact but not equally (1\%)

\section{BOTH}

Developed desirable outreach skills (1\%)

Table 3.14: Explanation of impact on career opportunities.

The common explanations for the impact on career opportunities attributed to working at CES were related to developing skills that are desired in a professional setting (16\%) such as project management experience (6\%), managing staff (3\%), and experience providing outreach (1\%). Additional impacts mentioned were focused on benefits associated with CES' reputation in the waste and recycling industry (4\%) including working with local government and industry professionals (4\%) and networking opportunities (14\%). Seven percent (7\%, 5 responses) of all the responses 
indicated their post-graduation employment was determined because of their position at CES.

Common responses for the impact on career opportunities from academic studies were focused on the value of a degree in the profession (10\%) and as a distinguishing factor over peers (3\%). This also includes the background knowledge provided through curriculum specific to that field (10\%). The primary response for other influences was the impact of previous employment.

\section{Discussion}

Key findings from the survey are presented in the two sections discussed below, competency development and influence on employment. Following the discussion of the findings from the survey is a discussion of the ways to further integrate CES with PSU's formal education programs to enhance students' competency development.

\section{Competency Development}

The first question addressed by this research was if CES alumni believed that they had developed the key sustainability competencies that the literature has identified as necessary. For each of the key sustainability competencies, a majority of respondents believed they had developed some level of proficiency (somewhat or very) in each. However, for each sustainability competency, there were not proficient responses (Table 3.1) indicating that development of sustainability competencies was not unanimous. While these findings align with the hypothesis that sustainability competencies were developed, a majority of the CES alumni attributed their 
development of all competencies to experiences working at CES and academic studies both equally (Table 3.2). For all competencies, more than $50 \%$ (for some competencies more than $60 \%$ ) of the respondents attributed their level of proficiency to both CES and academics equally. These findings support the literature that suggests a combination of formal (academic studies) and informal (CES) learning opportunities attribute to an effective sustainability education and student's development of sustainability competencies (Barth, Godmann, Rieckmann, \& Stolenberg, 2007). The value of connecting curricular programs where students develop sustainability content knowledge, and informal learning models (CES) that allow students to acquire skills through the application of knowledge, is echoed by a majority of the survey respondents attributing their competency development to both CES and their academic studies (Table 3.2) (Allen, Beaudoin, Lloyd-Pool, \& Sherman, 2014).

While PSU has a declaration of sustainability and goals to incorporate sustainability education into all colleges and programs (Portland State University, 2013a), the findings from the survey illustrate the range of competency development and level of proficiency between colleges and schools (Wiek, Withycombe, Redman, \& Mills, 2011; Robinson, 2008). Specific key sustainabilty competencies presented by Wiek, Withycombe, and Redman (2011) have not been adopted or integrated into PSU colleges and academic programs, but these findings demonstrate that the competencies can still be developed. Similar to PSU's commitment to incorporate sustainability education in all progragms across campus, a focus on community engagement and the 
application of knowledge to real-world problems is included in the university's mission and values that are intended to be reflected in all academic programs (Portland State University, 2015c). When CES alumni were asked to credit their development of each sustainability competency to experiences working at CES or their academic studies distinctively or both equally contributing, the majority believed they both equally contributed (Table 3.2). When this data is disaggregated by college and school (Table 3.7) a granular view of the responses selected by CES alumni underlines the unevenness across academic programs.

\section{$\underline{\text { Influence on Career and Employment }}$}

When asked which had more of an impact on their career and employment opportunities after graduation, $39 \%$ of survey respondents felt CES had a greater impact while 33\% felt CES and their academic program both equally influenced their career. Fourteen percent (14\%) reported their academic program, and $14 \%$ felt other influences had the greatest impact on their career. The real-world learning opportunities provided by CES creates a network of partnering organizations, businesses, and local government agencies who recognize CES graduates as potential employees, often facilitating postgraduate employment, which is not always a focus in higher education (Park, 2014).

When asked to provide an explanation of how their employability and career opportunities were affected, $7 \%$ of survey respondents noted that their employment post-graduation was determined because of their position at CES, while $14 \%$ of survey respondents felt the networking opportunities provided while working at CES had the 
greatest impact (Table 3.14). Additionally, $16 \%$ of survey respondents felt working at CES allowed them to develop professional skills through real-world experiences that directly influenced their career. The connections developed through working directly with local stakeholders, professionals, and government officials allowed students to develop a professional network before graduation that they could use immediately after graduation and throughout their career (Brian \& Thomas, 2013). The experiences from working on real-world projects and contracts at CES provide regular exposure to challenges such as communication styles, deadlines, and politics that cannot be taught in a classroom and are skills desired by employers and essential to professional success (Park, 2014; Wiek, Withycombe, Redman, \& Mills, 2011).

$\underline{\text { Integrating CES and Sustainability Curriculum }}$

While the survey results indicate that experiences working at CES help to influence career opportunities for students and when in conjunction with academic programs facilitate student development of sustainability competencies. A review of the literature highlights opportunities for CES to be more connected with sustainability education and curriculum. CES has created a strong industry specific knowledge base and has established a reputation of providing quality service to a variety of partners. This has also resulted in providing students with opportunities to develop professional skills while facilitating the development of sustainability competencies. However, by integrating CES and sustainability education curriculum at PSU, a more cohesive program that fully prepares students for sustainability careers can be accomplished. 
As mentioned in the beginning of this chapter, this research assumes that elements of sustainability are being incorporated into programs across campus creating a sustainability education curriculum as outlined in PSU's Declaration of Support for Sustainability (Portland State University, 2013a). As colleges and schools across campus become more familiar with sustainability education curriculum, they will be able to identify the elements of their program where they can deepen the connection to sustainability.

Within Brundiers and Wiek's (2011) framework for sustainability education, CES could further enhance its curricular connection by acting as a Transacademic Interface Manager (TIM) faciliating collaboration between partners and academia. As discussed in Chapter 1, the TIM provides additional support for transacademic (research that spans beyond the university and partners with stakeholders in the community) projects. This includes project management, faciliatation, and support for project participants to allow them to focus on their role. By performing this role, CES would continue to develop and deliver high-quality services for partners utilizing student employees, and would increase their collaboration with professors to provide real-world projects for classroom exercises and research. As outlined in the framework, as a TIM, CES would be providing project management oversight to ensure all components of the project are kept on track and providing necessary troubleshooting and facilitation between all participants. This position will provide additional support to professors allowing them to focus on mentoring students while providing experiences for students to develop sustainability 
competencies and professional skills--all while ensuring high-quality research and service is provided to partners (Brundiers \& Wiek, 2011).

By prioritizing the development of sustainability competencies and collaborating with academia, CES and PSU can make "sustainability education more practical and sustainability practice more effective" (Wiek, Withycombe, Redman, \& Mills, 2011, p. 11). The findings of this research demonstrated that CES alumni developed the identified sustainability competencies without a specific focus on competency development by CES as an organization. However, by evaluating existing practices and the development of competencies during CES projects, an understanding of the experiences and processes that facilitate competency development can be examined and replicated in future projects. This evaluation, coupled with identifying the competencies essential to successful sustainability projects and solutions can lead to a more transparent approach to provide real-world learning experiences aimed at developing sustainability competencies (Wiek, Withycombe, Redman, \& Mills, 2011). Increasing the connection between CES and sustainability education curriculum can build on existing learning environments by providing a more intentional path for students. This connection between CES and PSU curriculum has occurred in an ad hoc manner, largely due to the operational structure of CES that has limited capacity for non-project work. Recent curricular connections generally have been conducted within a professor's class where CES has provided industry expertise. CES student employees themselves have not benefitted from a connection to curriculum unless they seek it out 
and facilitate the process with their academic advisor. Increased integration with sustainability curriculum at PSU should benefit CES student employees as well as students in participating classes. 


\section{Chapter 4: Conclusion}

The purpose of this research has been to consider an informal learning model providing real-world learning opportunities and evaluate student development of competencies necessary for solving complex sustainability issues and the impact on student career opportunities. The sustainability competency literature highlights the value of real world and community-based learning to provide students with unique challenges not experienced in a classroom setting to facilitate the development of sustainability competencies. Portland State's rich history of community-based learning, coupled with the institution's commitment via its declaration of sustainability that prioritizes sustainable practices and education, has established multiple opportunities where students could develop sustainability competencies. One example is Community Environmental Services, a research and service unit at PSU that has been providing realworld projects for students working with community partners to address waste, recycling, and materials management issues. To contribute to the literature on sustainability competency development through community-based and real world learning, this research focused on CES alumni and their development of sustainability competencies.

This research found that CES alumni, at the time they left CES and/or PSU, believed they were proficient in each of the sustainability competencies, and attributed their development of those competencies to the combination of working at CES and their academic program. These findings support reports in the literature that suggest 
that a combination of formal and informal learning environments providing real-world learning opportunities help students develop sustainability competencies. The CES alumni survey also found that for a majority of alumni, experiences working at CES including the opportunity to network and develop professional skills through real-world experiences - had a greater impact on career and employment than their academic program. This research also provided opportunities for CES to further connect with PSU's curriculum to provide support for students to develop sustainability competencies.

\section{$\underline{\text { Research Needs }}$}

Additional research is needed to provide insight into how CES as an organization facilitates student competency development. By analyzing structural and operational elements of CES combined with an evaluation student development of sustainability competencies during real-world projects, the specific experiences that facilitate competency development can be identified. Additionally, a similar evaluation and testing of students' development of competencies should occur during their academic studies at PSU. This additional research could provide support for developing programs to facilitate proficiency in sustainability competencies.

Once it is understood how CES alumni are developing sustainability competencies, additional research is necessary to address the use and value of competencies post-graduation to solve sustainability issues. This would supplement the existing literature that identifies sustainability competencies but does not have evidence 
that demonstrates how sustainability education graduates are solving sustainability issues beyond academia (Wiek, Withycombe, \& Redman, 2011). Further analysis of CES alumni who stayed in the sustainability field could provide an evaluation of sustainability competencies from a professional perspective, and connect sustainability competencies to professionals making "sustainability education more practical and sustainability practice more effective" (Wiek, Withycombe, Redman, \& Mills, 2011, p. 11). 


\section{Works Cited}

Allen, J. H., Beaudoin, F., Lloyd-Pool, E., \& Sherman, J. (2014). Pathways to Sustainability Careers: Building Capacity to Solve Complex Problems. Sustainability, 7(1), 47-53.

Barth, M., Godmann, J., Rieckmann, M., \& Stolenberg, U. (2007). Developing key competencies for sustaianble development in higher education. International Journal of Sustainability in Higher Education, 8(4), 416-430.

Batie, S. S. (2008). Wicked PRoblems and Applied Economics. American Journal of Agricultural Economics, 90(5), 1176-1191.

Brian, R. G., \& Thomas, B. H. (2013). Undergraduate Students as Sustainability Consultants: Applying Service-Learning to Enhance Career Skills and Foster Community Environmental Sustainability. Sustainability, 6(5), 277-281.

Brundiers, K., \& Wiek, A. (2011). Educating Students in Real-world Sustainability Research: Vision and Implementation. Innovation in Higher Education, 36, 107124.

Brundiers, K., Wiek, A., \& Redman, C. L. (2010). Real-world learning opportunities in sustainability: from classroom into the real world. International Journal of Sustainability in Higher Education, 11(4), 308-324.

Community Environmental Services. (2003). Community Environmental Services Mission Statement. 
Community Environmental Services. (2015a). City of Portland. Retrieved from College of Urban \& Public Affairs: Community Environmental Services: http://www.pdx.edu/ces/city-of-portland Community Environmental Services. (2015b). Materials Assessment Services. Retrieved from College of Urban \& Public Affairs: Community Environmental Services: http://www.pdx.edu/ces/materials-assessment-services Community Environmental Services. (2015c). Metro Regional Government. Retrieved from College of Urban \& Public Affairs: Community Environmental Services: http://www.pdx.edu/ces/metro-regional-government Community Environmental Services. (2015d). Port of Portland. Retrieved from College of Urban \& Public Affairs: Community Environmental Services: http://www.pdx.edu/ces/port-of-portland de Haan, G. (2006). The BLK '21' programme in Germany: a 'Gestaltungskompetenz'based model for Education for Sustainable Development. Environmental Education Research, 12(1), 19-32.

Kecskes, K., Kerrigan, S., \& Patton, J. (2006). The Heart of the Matter: Aligning Curriculum, Pedagogy and Engagement in Higher Education. Metropolitan University Journal.

Liu, J., \& al., e. (2007). Complexity of Coupled Human and Natural Systems. Science, 317, 1513-1516. 
Miller, T., Baird, T., Littlefield, C., Kofinas, G., \& F. Stuart Chapin, I. (2008).

Epistemological Pluralism: Reorganizing Interdisicplinary Research. Ecology and SOciety, 13(2).

Park, J. (2014). Education and Career Pathways for Sustainability in an Era of Disruptive Change, Part 1. Sustainability, 7(1), 21-26.

Park, J. (2014). Education and Career Pathways for Sustainability in an Era of Disruptive Change, Part 2. Sustainability, 7(2), 86-89.

Port of Portland. (2014). Environmental Programs. Retrieved from Inside the Port: http://www.portofportland.com/PDFPOP/Env_Home_13_14_RsItsObjTrgts.pdf Portland State University. (2013a). PSU: Declaration of Support for Sustainability. Retrieved from Portland State University: http://www.pdx.edu/sustainability/sites/www.pdx.edu.sustainability/files/psu_s ust_declaration.pdf

Portland State University. (2013b). Sustainability at Portland State University Playbook 2013-2018. Retrieved from Portland State University: http://www.pdx.edu/sustainability/sites/www.pdx.edu.sustainability/files/Playb ook_DEC_final.pdf

Portland State University. (2014). Portland State University Strategic Plan 2011-2014. Retrieved from Portland State University: http://www.pdx.edu/president/sites/www.pdx.edu.president/files/PSU.SPwithU pdate.pdf 
Portland State University. (2015a). About CES. Retrieved from College of Urban \& Public Affairs: Community Environmental Services: http://www.pdx.edu/ces/about-ces Portland State University. (2015b). Institute for Sustainable Solutions. Retrieved from Portland State University: http://www.pdx.edu/sustainability/iss Portland State University. (2015c). Portland State University Mission. Retrieved from Portland State University: http://www.pdx.edu/portland-state-universitymission

Portland State University. (2015d). Snapshot of Portland State. Retrieved from Portland State University: http://www.pdx.edu/profile/snapshot-portland-state

Rittel, H. W., \& Webber, M. M. (1973). Dilemmas in a General Theory of Planning. Policy Sciences, 4, 155-169.

Robinson, J. (2008). Being undisciplined: Transgressions and intersections in academia and beyond. Futures, 40, 70-86.

Rowe, D. (2007). Education for a Sustainable Future. Science, 323-324.

Schugurensky, D. (2000). The forms of informal learnign: towards a conceptulization of the field.

Steinemann, A. (2003). Implementing Sustainable Development through Problem-Based Learning: Pedagogy and Practice. Journal of Professional Issues in Engineering Education and Practice, 216-224.

United Nations. (2008). Decade of Education for Sustainable Development. Retrieved from http://www.desd.org/about.html 
Wiek, A., Withycombe, L., \& Redman, C. (2011). Key competencies in sustainability: a reference framework for academic program development. Sustainable Science, $6,203-218$.

Wiek, A., Withycombe, L., Redman, C., \& Mills, S. B. (2011). Moving Forward on Competence in Sustainability Research and Problem Solving. Environment: Science and Policy for Sustainable Development, 53(2), 3-12.

Wiewel, W., Kecskes, K., \& Martin, S. (2011, November). Portland State University's Second (R)evolution: Partnering to Anchor the Institution in Sustainable Communities. Metropolitan Universities, 22(2), 8-19. 


\section{Appendix: CES Alumni Survey}

Erin Lorene Anderson, from the Nohad A. Toulan School of Urban Studies and Planning at Portland State University (PSU), is conducting this research study for her Masters of Urban Studies. This research is focusing on student development of skills and competencies while working at Community Environmental Services (CES) and attending PSU. You are being invited to participate in this study because while attending PSU you were employed by CES. Your participation will involve a short survey with multiple choice and open ended questions that will take about 15 minutes to complete. Your involvement in the study is voluntary, and you may choose not to participate. There are no names or identifying information associated with this survey. This survey includes questions such as "please rate your level of proficiency in strategic competence at the time you left CES and PSU" and "which had more impact on your employability and career opportunities." You can refuse to answer any of the questions at any time. There are no known risks in this study, but some individuals may experience discomfort when answering questions. The findings from this project will provide information on the development of skills and competencies of PSU students who worked at CES and if the student feels their experiences at CES or academic studies facilitated their development. If published, results will be presented in summary form only. If you have any questions about this research project, please feel free to contact Erin Lorene Anderson at Lorene@pdx.edu or 503-725-8371. If you have questions regarding your legal rights as a research subject, you may call the PSU Office of Research Integrity at 503-725-2227. By clicking Accept, you are consenting to participate in this research. By clicking "Decline", you will be directed away from the survey. Thank you for your consideration.

Accept (1)

Decline (2)

If Decline Is Selected, Then Skip To End of Survey

Q1.1 The following are introductory questions about your time working at CES and academic studies at PSU.

Q1.2 When did you begin working at CES? (yyyy)

Q1.3 How long did you work at CES?

Q1.4 What project(s) did you work on?

Q1.5 What positions or type of work did you do while at CES? (For example, waste sort staff, field work, outreach, project lead, etc.)

Q1.6 What academic degree or program were you enrolled in while at PSU? 
Q2.1 The following questions utilize five competencies identified in sustainability education literature as a framework. Please reflect on your experiences working at CES and your academic studies at PSU to provide the level of proficiency for each competency at the time you left CES or PSU.

Q2.2 Systems-thinking competence is defined as the ability to analyze complex systems across different fields (environment, society, economy, etc.) and scales (local to global) while considering systemic features and problem-solving frameworks related to sustainability issues.

Q2.3 At the time you left CES or PSU, your level of proficiency related to systemsthinking competence was

Not proficient (1)

Somewhat proficient (2)

Very proficient (3)

If Not proficient Is Selected, Then Skip To Anticipatory competence is defined as...

Q2.4 Which would you attribute that to?

Working at CES (1)

Your academic studies (2)

Both equally (3)

Q2.5 Anticipatory competence is defined as the ability to analyze, evaluate, and articulate the long-term future of various sustainability issues, including unintended consequences and inter-generational equity.

Q2.6 At the time you left CES or PSU, your level of proficiency related to anticipatory competence was

Not proficient (1)

Somewhat proficient (2)

Very proficient (3)

If Not proficient Is Selected, Then Skip To Normative competence is defined as th...

Q2.7 Which would you attribute that to?

Working at CES (1)

O Your academic studies (2)

Both equally (3)

Q2.8 Normative competence is defined as the ability to convey, apply, and negotiate sustainability values, goals, and targets. This includes the ability to first assess the current issue and then the ability to create a more sustainable vision for that issue. 
Q2.9 At the time you left CES or PSU, your level of proficiency related to normative competence was

Not proficient (1)

Somewhat proficient (2)

Very proficient (3)

If Not proficient Is Selected, Then Skip To Strategic competence is defined as th...

Q2.10 Which would you attribute that to?

Working at CES (1)

Your academic studies (2)

Both equally (3)

Q2.11 Strategic competence is defined as the ability to "get things done" by designing and implementing interventions and transformative strategies toward improved sustainability. Requires familiarity with real-world situations and relationships, political understanding, power structures and relationships, ability to convey technical issues in layman's terms, and to meet deadlines.

Q2.12 At the time you left CES or PSU, your level of proficiency related to strategic competence was

Not proficient (1)

Somewhat proficient (2)

Very proficient (3)

If Not proficient Is Selected, Then Skip To Interpersonal competence is defined a...

Q2.13 Which would you attribute that to?

Working at CES (1)

Y Your academic studies (2)

O Both equally (3)

Q2.14 Interpersonal competence is defined as the ability to motivate, enable, and facilitate collaborative and participatory sustainability research and problem solving. Ability to understand, compare, and critically evaluate different positions, perspectives, and preferences.

Q2.15 At the time you left CES or PSU, your level of proficiency related to interpersonal competence was

Not proficient (1)

Somewhat proficient (2)

Very proficient (3)

If Not proficient Is Selected, Then Skip To Are there skills, knowledge, or abilities 
Q2.16 Which would you attribute that to?

Working at CES (1)

O Your academic studies (2)

Both equally (3)

Q2.17 Are there skills, knowledge, or abilities not mentioned that you developed during your time working at CES that you feel are essential to a professional?

Q2.18 Are there skills, knowledge, or abilities not mentioned that you developed through your academic studies at PSU that you feel are essential to a professional?

Q3.1 Which had more impact on your employability and career opportunities?
O Working at CES (1)
Your academic studies (2)
Both equally (3)
Other (4)

Q3.2 Please explain how your selection from the above question had an impact on your employability and career.

Q4.1 Please provide any additional thoughts that were not covered in this survey related to your experience working at CES, your academic studies at PSU, and the competencies and skills that you've developed which have benefited your career. 